\title{
Differential resource selection within shared habitat types across spatial scales in sympatric toads
}

\author{
Lukas Indermaur, ${ }^{1,2,8}$ Thomas Winzeler, ${ }^{1,2}$ Benedikt R. Schmidt, ${ }^{3,4}$ Klement Tockner,${ }^{1,2,5}$ \\ and Michael Schaub 6,7 \\ ${ }^{1}$ Eawag, Swiss Federal Institute of Aquatic Science and Technology, Department of Aquatic Ecology, Überlandstrasse 133, \\ 8600 Dübendorf. Switzerland \\ ${ }^{2}$ ETH, Swiss Federal Institute of Technology, Institute of Integrative Biology, 8092 Zürich, Switzerland \\ ${ }^{3}$ Zoologisches Institut, Universität Zürich, Winterthurerstrasse 190, 8057 Zürich, Switzerland \\ ${ }^{4}$ Koordinationsstelle für Amphibien und Reptilienschutz in der Schweiz (KARCH), Passage Maximilien de Meuron 6 , \\ 2000 Neuchâtel, Switzerland \\ ${ }^{5}$ Institut für Gewässerökologie und Binnenfischerei (IGB), Leibniz Institute of Freshwater Ecology and Inland Fisheries, \\ and Institute of Biology, Freie Universität Berlin, Mueggelseedamm 310, 12587 Berlin, Germany \\ ${ }^{6}$ Swiss Ornithological Institute, 6203 Sempach, Switzerland \\ ${ }^{7}$ Institute of Ecology and Evolution, Conservation Biology, University of Bern, Baltzerstrasse 6, 3012 Bern, Switzerland
}

Abstract. Differential habitat selection is a central component in the evolution of species, but it has been quantified rarely for sympatric species in relation to the multiple impacts of resources at the spatial scales at which animals operate. Our main goal was to quantify the selection of terrestrial summer habitats in a natural floodplain in Italy by two sympatric amphibians (Bufo bufo spinosus and B. viridis) as a function of habitat type, prey density, and temperature. We applied a Bayesian resource selection model at three spatial scales: (1) home range placement within the floodplain, (2) space use within 95\% home ranges, and (3) space use within 50\% core areas. Using these data we explored whether processes acting at large scales lead to space use patterns at small scales and whether the two species use the same habitat types in a way that would facilitate coexistence.

Habitat selection was determined by habitat type, prey density, and temperature at all spatial scales, resulting in slightly higher prey density and significantly lower temperature within than outside home ranges. We conclude that amphibians perceive the distribution of habitat types as well as gradients in prey density and temperature at all spatial scales. The effects of habitat type dominated home range placement while prey density and temperature most strongly affected space use within home ranges. Our results suggest that home range placement relies on broad habitat features that indicate resource availability at small spatial scales. At the smallest spatial scale, the selection of prey and refugia is most probably facilitated due to the accumulation of environmental information as animals may sample the entire area.

Both species largely preferred the same habitat types, but used them differently in relation to resources across the three spatial scales. For example, while one species used the same habitat type for foraging, the other used it for resting or both resting and foraging. Niche differentiation through differential resource selection within shared habitat types at all spatial scales may therefore facilitate the coexistence of the two species in terrestrial summer habitats.

Key words: amphibian; Bufo bufo spinosus; Bufo viridis; coexistence; floodplain river; foraging behavior; hierarchical habitat selection; home range; Italy; niche differentiation; resource gradient; thermoregulation.

\section{INTRODUCTION}

Coexistence of species can arise through avoidance of competition (Gause 1934, Hardin 1960). Competition may be avoided through the spatiotemporal partitioning of habitats and resources (Hairston 1951, Whittaker 1967, Pianka 1969, Diamond 1973). In this context, differential habitat selection is a key process that stabilizes the coexistence of species (MacArthur and

Manuscript received 13 May 2008; revised 5 March 2009; accepted 6 March 2009. Corresponding Editor: J. Van Buskirk.

${ }^{8}$ E mail: lukas.indermaur@eawag.ch
Levins 1967, Rosenzweig 1991, Chesson 2000). The study of differential habitat selection requires environ mental information at all the spatial and temporal scales at which animals operate (Hutchinson 1957, Wiens 1973). This information can be methodologically diffi cult to obtain, perhaps explaining why the combined effects of multiple resources on habitat selection of sympatric species have been rarely studied empirically (Anthony and Smith 1977, Bourget et al. 2007, Gilbert et al. 2008). To understand habitat selection as a potential mechanism for coexistence and to assess the importance of differential habitat selection, we need to explore the interplay of various resources and their gradients on 
habitat selection of sympatric species across multiple spatial scales.

Habitat selection is a spatially hierarchical process. Animals first place home ranges within a larger area and subsequently use patches within home ranges (Johnson 1980). Home range placement is the most important behavioral decision, as it determines the number of patches for exploitation. This then determines resource availability and conditions at smaller spatial scales. Animals are unable to sample every patch when settling within large areas. Hence, home range placement is usually based on broad features of the environment such as habitat types, which should indicate the availability of all key resources (Lack 1940, MacArthur et al. 1966, Cody 1981). Subsequent space use within home ranges is conditional on home range placement and is governed by the resources that are most important at smaller spatial scales such as food availability or thermal and predatory refugia (Rettie and Messier 2000, Chalfoun and Martin 2007). Hierarchical habitat selection is therefore thought to be a solution to cope with spatial variation in resource availability and conditions (Levins 1968, Orians and Wittenberger 1991), an idea that has found empirical support (Nikula et al. 2004, Pinaud and Weimerskirch 2005, Beasley et al. 2007, Ciarniello et al. 2007).

The hierarchical nature of habitat selection suggests that different environmental factors determine habitat selection at different spatial scales (Kie et al. 2002, Börger et al. 2006). Even within home ranges, where patches are repeatedly traversed during daily activities, the ecological relevance of factors can change. This seems intuitive as home ranges are the spatial expression of animal movements and thus integrate different behaviors such as resting, nesting, foraging, and avoidance of predators (Burt 1943). Animals may use different areas within home ranges for different behav iors due to the spatial distribution of different resources (Marzluff et al. 2001, Indermaur et al. 2009). Exploring the relative importance of factors governing habitat selection across spatial scales can therefore shed light on the decision rules underlying animal movements (Rosh ier et al. 2008).

We quantified the selection of terrestrial summer habitats of two pond breeding amphibians, the Europe an common toad Bufo bufo spinosus and the green toad $B$. viridis, in a riverine floodplain in Italy where they co occur (Tockner et al. 2006). We studied the terrestrial summer period because of its importance for population viability (Schmidt et al. 2005, Harper et al. 2008). In summer, the factors most important for the survival of these amphibians are the availability of prey and the availability of refugia. Abundant prey is required to build up fat reserves for physiological maintenance and future reproduction (Wälti and Reyer 2007), while refugia are needed for thermoregulation and avoidance of predators (Schwarzkopf and Alford 1996, Seebacher and Alford 2002). Within the summer home ranges, small interior core areas and large peripheral areas are used for different behaviors. Indermaur et al. (2009) concluded that $B$. viridis used the peripheral areas around the core areas (95\% home ranges) for foraging and used the interior of home ranges ( $50 \%$ core areas, 10 times smaller than $95 \%$ home ranges) for resting (thermoregulation and escape from predators). Bufo bufo spinosus used the core areas for both resting and foraging but the $95 \%$ home range solely for foraging.

Our main goal was to analyze habitat selection as a function of habitat type, a biotic resource (prey density), and an abiotic condition (temperature) at three spatially hierarchical scales. We used a Bayesian approach to fitting resource selection models to: (1) home range placement within the floodplain, (2) space use within $95 \%$ of home ranges, and (3) space use within $50 \%$ of core areas. We hypothesized that home range placement is determined by habitat type, prey density, and temperature. Otherwise, relevant resources would not be available at smaller scales. The $95 \%$ home range is mainly used for foraging, and we therefore expected that habitat use withinthe home range is determined by prey density. Both species rest and seek shelter primarily within the $50 \%$ core area. As thermal conditions within shelters determine their suitability for resting, we expected that temperature determines space use within core areas. Quantifying hierarchical resource selection seems promising to explore whether processes acting at large scales lead to space use patterns at small scales. In addition, our approach is promising to shed light on the mechanism underlying the coexistence of species. For the two species to coexist within the floodplain, we expect that the same habitat types are used differently in relation to prey density and temperature at least at one spatial scale.

\section{Methods \\ Study site}

The study was conducted from mid June through September in 2005 and 2006 on the seventh order Tagliamento River in northeastern Italy $\left(46^{\circ} \mathrm{N}, 12^{\circ} 30^{\prime}\right.$ E). The Tagliamento (catchment area $2580 \mathrm{~km}^{2}$ ) originates at $1000 \mathrm{~m}$ above sea level (asl) in the southern European Alps and flows almost unimpeded by dams for $172 \mathrm{~km}$ to the Adriatic Sea. The Tagliamento floodplain is characterized by summer droughts and retains its essentially pristine morphological and hydro logical characteristics. The main study area was the active tract $\left(1.1 \mathrm{~km}^{2}\right)$ of an island braided floodplain complex (river $\mathrm{km} 79.8$ 80.8; $135 \mathrm{~m}$ asl). The study reach contains a spatially complex and temporally dynamic mosaic of water bodies, large wood deposits, pioneer vegetation, and vegetated islands, embedded into an extensive matrix of exposed riverine sediments (Petts et al. 2000, Indermaur et al. 2009; Appendix A). The active tract is $650 \mathrm{~m}$ wide and bordered by riparian forest, with the steep hillslope of Monte Ragogna on the eastern side. Detailed information on the Tagliamento 
TABLE 1. Mean spatial extent (in hectares and percentage of total floodplain area) of all habitat types and the distribution of locations in $95 \%$ home ranges for the European common toad (Bufo bufo spinosus) and the green toad (B. viridis).

\begin{tabular}{|c|c|c|c|c|c|c|c|c|c|c|c|c|c|}
\hline \multirow[b]{3}{*}{ Code } & \multirow[b]{3}{*}{ Habitat type } & \multirow{2}{*}{\multicolumn{2}{|c|}{$\begin{array}{l}\text { Availability } \\
(A \quad \% \text { area })\end{array}$}} & \multicolumn{6}{|c|}{ Used ( $U \quad \%$ locations) } & \multirow{2}{*}{\multicolumn{2}{|c|}{$\begin{array}{l}\text { Mean maximum } \\
\text { temperature }\left({ }^{\circ} \mathrm{C}\right) \dagger\end{array}$}} & \multirow{2}{*}{\multicolumn{2}{|c|}{$\begin{array}{c}\log (\text { prey } \\
\text { density }\left(\mathrm{m}^{2}\right) \ddagger\end{array}$}} \\
\hline & & & & \multicolumn{3}{|c|}{ Bufo bufo spinosus } & \multicolumn{3}{|c|}{ Bufo viridis } & & & & \\
\hline & & (ha) & $(\%)$ & $n$ & $(\%)$ & $U / A$ & $n$ & $(\%)$ & $U / A$ & Mean & SD & Mean & $\mathrm{SD}$ \\
\hline GRA & $\begin{array}{l}\text { exposed gravel } \\
\text { sediments }\end{array}$ & 70.32 & 67.6 & 701 & 23.3 & 0.34 & 1131 & 46.2 & 0.68 & 43.3 & 3.1 & 0.199 & 0.367 \\
\hline LWD & large wood deposits§ & 1.26 & 1.2 & 589 & 19.6 & 16.12 & 850 & 34.8 & 28.59 & 27.2 & 2.2 & 0.182 & 0.374 \\
\hline PV & $\begin{array}{l}\text { dense pioneer } \\
\text { vegetation }\end{array}$ & 3.98 & 3.8 & 248 & 8.3 & 2.15 & 227 & 9.3 & 2.42 & 35.4 & 2.8 & 0.440 & 0.402 \\
\hline ISL & established islands\# & 8.3 & 8.0 & 693 & 23. & 2.88 & 27 & 1.1 & 0. & 33 & & 0.7 & 0.360 \\
\hline ISLE & island edge $\|$ & 6.48 & 6.2 & 753 & 25.0 & 4.02 & 205 & 8.4 & 1.34 & 34.8 & 4.2 & 0.171 & 0.308 \\
\hline \multirow[t]{2}{*}{ WAT } & watertt & 13.59 & 13.1 & 22 & 0.7 & 0.06 & 6 & 0.2 & 0.02 & & & & \\
\hline & Total & 103.97 & 100.0 & 3006 & 100.0 & & 2446 & 100.0 & & & & & \\
\hline
\end{tabular}

Notes: The mean values for 2005 and 2006 data are presented. The relative intensity of habitat use is given by the proportions of locations $(U)$ over the proportion of available habitat $(A)$, where $U / A<1$ denotes habitat types that were less used compared to their availability. The study was conducted from mid June through September in 2005 and 2006 on the seventh order Tagliamento River in northeastern Italy.

$\dagger$ Based on 124 temperature loggers that were distributed proportionally over the habitat types. Mean maximum temperature was calculated using hourly measures from 08:00 to 20:00.

$\ddagger$ Based on 100 pitfall traps that were distributed proportionally over the habitat types. Pitfalls were sampled on three occasions in summer.

$\S$ Minimum size of $0.5 \mathrm{~m}^{2}$.

ब Vegetation cover $>50 \%$; minimum size of $1 \mathrm{~m}^{2}$.

\# Island with wooded perennial vegetation of mostly poplars (Populus nigra) taller than $2 \mathrm{~m}$, surrounded by water or exposed gravel.

|| Dense vegetation at the edge of established islands with a general width of $10 \mathrm{~m}$, largely composed of different willow species and poplars. The island edge is a refugia rich border with slopes between $45^{\circ}$ and $90^{\circ}$.

$\dagger \dagger$ Not considered for analysis because of its availability only to a few animals.

catchment and the main study area can be found elsewhere (Ward et al. 1999, Arscott et al. 2002, Tockner et al. 2003).

\section{Study species}

Bufo bufo spinosus (European common toad) is a widespread species and typically associated with densely vegetated habitats of late successional stages. Bufo viridis (green toad) is a characteristic species of the hot continental and Mediterranean steppes and prefers early succession habitats (Giacoma and Castellano 2006). Bufo viridis travels farther while foraging than $B . b$. spinosus (Indermaur et al. 2009). Both species may burrow to withstand harsh environmental conditions. An earlier study of these species at the same locality found that the composition of prey was similar for the two toad species, but that prey density was twice as high in densely vegetated habitats mainly occupied by $B . b$. spinosus compared with the open habitats mainly occupied by B. viridis (Indermaur et al. 2009).

\section{Habitat mapping}

In 2005 and 2006, the entire study area was mapped in detail at base flow $\left(\sim 20 \mathrm{~m}^{3} / \mathrm{s}\right)$ using a differential GPS (Trimble GeoXT, Trimble, Sunnyvale, California, USA) (Appendix B). The GPS data were processed using ArcView GIS 9.0 (Environmental Systems Research Institute, Redlands, California, USA). We discriminated six habitat types that were mutually exclusive: exposed gravel sediments (70.3 ha; average values for both years), water (13.5 ha), established islands (8.3 ha), edge of established islands (6.4 ha), dense pioneer vegetation (3.9 ha), and area of large wood deposits (1.2 ha) (Table 1). The habitat type water was excluded for analysis because it was used rarely by only a few toads. The edge of established islands was included because edge habitat can provide complementary food resources (Morris 1987).

\section{Determinants of habitat selection}

Four explanatory factors were used for modeling the selection of $1 \mathrm{~m}^{2}$ grid cells: $\log$ (prey density) (Pd), temperature $(T)$, habitat type ( $\mathrm{Ht}$, five levels), and species ( $S$, two levels). A single habitat type (Table 1) was assigned to each grid cell. We chose grid cells of 1 $\mathrm{m}^{2}$ resolution because animals rarely used smaller areas of the most preferred habitat type (large wood deposits; see Results).

Temperature and prey density were calculated as follows: temperature loggers (Maxim thermochron ibuttons DS1921G [Maxim Integrated Products, Sunny vale, California, USA], $0.5^{\circ} \mathrm{C}$ resolution, $\pm 1^{\circ} \mathrm{C}$ accuracy from $30^{\circ} \mathrm{C}$ to $70^{\circ} \mathrm{C}$; 2005, 67 loggers; 2006, 57 loggers) were randomly distributed in proportion to the area cover of individual habitat types. Temperature was logged at the sediment surface at hourly intervals. Every habitat type showed a similar temperature pattern over the season (parallel temperature curves); therefore we assigned a habitat type specific mean maximum day temperature to each corresponding grid cell. These assigned temperature values were linearly weighted using measured temperature gradients across the flood 
plain in order to better reflect the temperature variation within habitat types. Specifically, temperature decreased from island cores to the island edge by $1.3^{\circ} \mathrm{C}$ and from the island edge until $10 \mathrm{~m}$ into exposed gravel sediments by $8.5^{\circ} \mathrm{C}$. Gravel was $3.8^{\circ} \mathrm{C}$ cooler between proximal islands than distant islands, and northern edges of islands were, on average, $4^{\circ} \mathrm{C}$ cooler than southern edges.

Prey density was quantified in 2006 by arrangement of 100 pitfall traps $(9 \mathrm{~cm}$ diameter, $12 \mathrm{~cm}$ depth, $0.5 \mathrm{~L}$ volume) randomly along three transects perpendicular to the river corridor. The traps were sampled three times in 2006 (21 and 22 July, 8 and 9 August, 7 and 8 September) and were opened (set) at twilight (20:00 21:30) and closed at sunrise (05:00 07:00). Assuming that all the contents of the pitfall traps were consumable, mean prey density within the active tract was determined per sampling date by applying an inverse distance weighted interpolation method in ArcGIS 9.0 using log transformed prey densities. We used interpolated values instead of assigning average habitat type specific prey densities to grid cells to reflect the large variation in prey density within habitat types observed. Inverse distance weighting models work on the premise that observations farther away should have their contributions diminished according to how far away they are (de Smith et al. 2006). The three interpolations were averaged, and the fit of the averaged cross validated interpolation was assessed $\left(R^{2}=0.466\right)$.

\section{Radiotelemetry}

Adult toads were caught during random searches at night, at the end of the breeding season, and marked with radio transmitters LT2 351 (2 g) or LT2 392 (5 g) (Titley Electronics, Ballina, New South Wales, Austra lia). The radio transmitters were tightly fitted with an aluminium beaded chain belt (Ball Chain Manufactur ing, Mount Vernon, New York, USA) around the waist (Rathbun and Murphey 1996, Indermaur et al. 2008). The mass of the transmitter, including the belt, did not exceed $10 \%$ of the body mass of toads (B. b. spinosus, $4.32 \% \pm 1.51 \%$; B. viridis, $6.86 \% \pm 0.94 \%$ [mean $\pm \mathrm{SD}]$ ) as recommended by Richards et al. (1994). As reported elsewhere, environmental factors explained changes in individual toad body mass better than transmitter mass and duration of the tracking period (Indermaur et al. 2008). We therefore assume that any bias in movement data due to tracking methods is minimal.

Australis 26k scanning receivers and hand held three element Yagi antennas (Model AY/C, Yagi collapsible; Titley Electronics) were used for tracking toads. We followed 56 radio tagged $B$. b. spinosus and 59 B. viridis between one and three months $(B . b$. spinosus, mean $=$ $44.5 \mathrm{~d}$, range $=13.499 .5 \mathrm{~d} ;$ B. viridis, mean $=33.1 \mathrm{~d}$, range $=13.571 \mathrm{~d}$ ). The exact position of each toad was recorded six days per week, once during the day and once at night, using a differential GPS (average tracking resolution, $1 \mathrm{~m}$ ). Two observers simultaneously located toads in different parts of the study area, randomly varying the tracking time and the sequence of tracked animals.

\section{Estimation of home ranges}

For home range estimation, 3079 locations of $56 \mathrm{~B} . \mathrm{b}$. spinosus and 2545 locations of 59 B. viridis that were collected in 2005 and 2006 were used. On average, we obtained $55 \pm 27.6$ (mean \pm SD) locations for each individual of B. b. spinosus and $43 \pm 16$ locations of each individual of $B$. viridis. Fixed kernel home ranges were calculated with software Ranges 7 (grid, $160 \times 160$ cells; cell size, $1 \mathrm{~m}^{2}$ ) using either $50 \%$ or $95 \%$ of the locations (Kenward and Hodder 1996) and by applying a least squares cross validated smoothing factor $(h=0.3)$. In 95\% home ranges and 50\% core areas, toads spend approximately $95 \%$ or $50 \%$ of their time, respectively. The $50 \%$ core area was determined by applying a regression of probability of use against the proportion of total area (Clutton Brock et al. 1982, Powell 2000, Indermaur et al. 2009). The 50\% core area was 10 times smaller than the $95 \%$ home range and located at the interior of the home range (Indermaur et al. 2009; Fig. 1).

\section{Statistical analysis}

We quantified habitat selection for each individual at three spatial scales: (1) home range placement within the floodplain, (2) space use within 95\% home ranges, and (3) space use within $50 \%$ core areas. For analyses, we used only the radio locations $(n)$ of 2006 because prey density was not sampled in 2005: 27 individuals of $B . b$. spinosus and 32 individuals of $B$. viridis (home range placement, B. b. spinosus, $n=1354$, B. viridis, $n=1379$; space use within $95 \%$ home ranges, $B$. b. spinosus, $n=$ 1229 , B. viridis, $n=1347$; space use within $50 \%$ core areas, B. b. spinosus, $n=665, B$. viridis, $n=793$ ).

Used/available design. We quantified the amount of used habitat (number of $1 \mathrm{~m}^{2}$ grid cells in which an animal was located) and available habitat (all $1 \mathrm{~m}^{2}$ grid cells) per species and spatial scale. Hence, the amount of used and available grid cells varied per individual of both species and spatial scale. A random sample of available grid cells per individual was chosen in proportion to used grid cells as done by Engler et al. (2004), because the power of logistic regression models to detect effects is maximal when the expected selection probability is 0.5 . When individuals place home ranges within the floodplain, the entire floodplain habitat (552822 grid cells) is available for selection. Because some animals crossed the entire study area within a single night (L. Indermaur, unpublished data), we considered all grid cells within the study area to be available to animals. Similarly, all grid cells within home ranges and core areas potentially could be used by animals, thus we varied habitat availability per individ ual across spatial scales in proportion to used habitat (Fig. 1). 


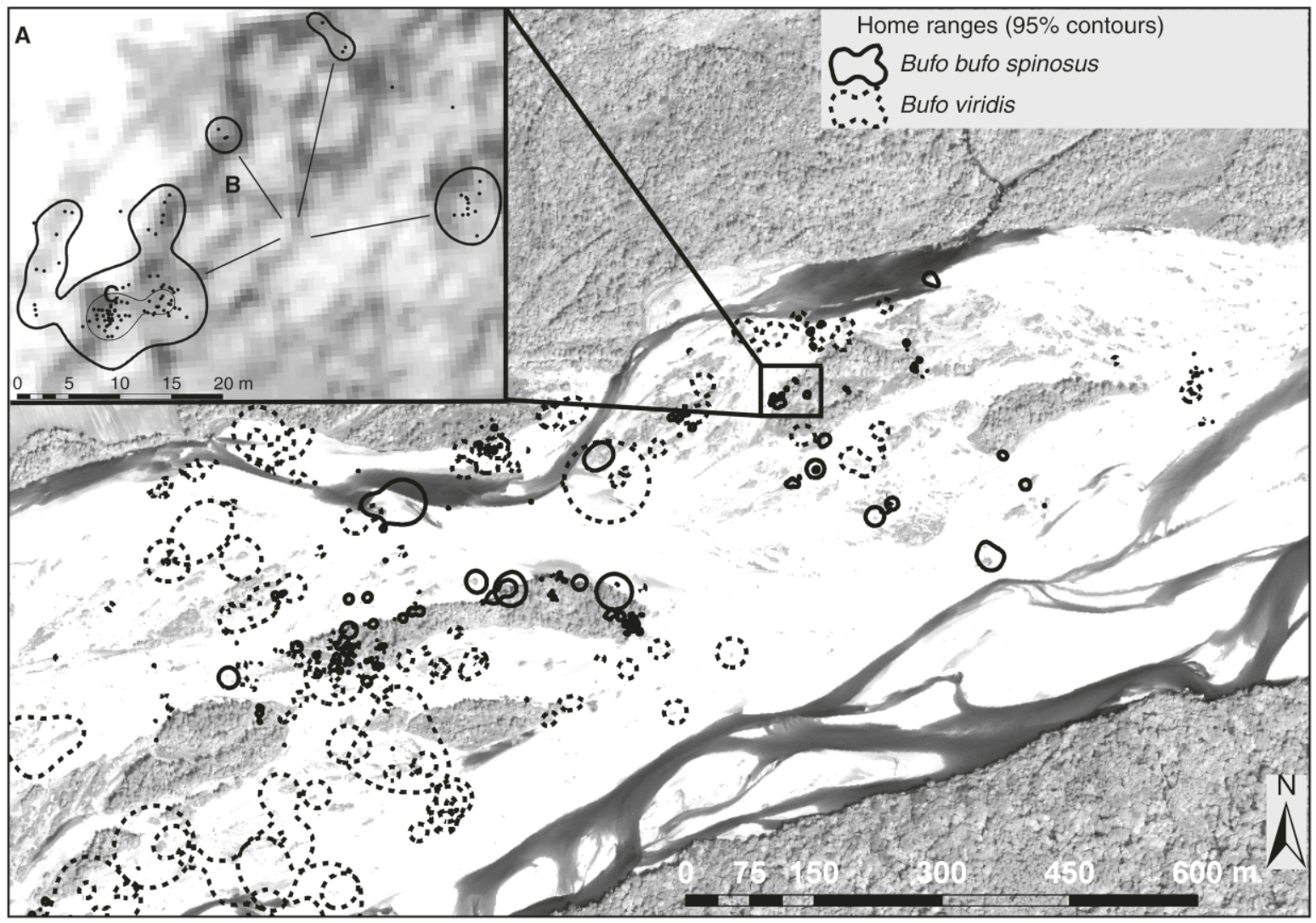

FIG. 1. Part of the distribution of home ranges (95\% contours) of the European common toad (Bufo bufo spinosus) and the green toad (B. viridis) in the study site, the seventh order Tagliamento River in northeastern Italy (2006 data). Riparian forest fringes the active tract, which is mainly composed of exposed gravel sediments (white), the river network (dark gray), dense pioneer vegetation, and established islands (pale gray). The inset shows the multi nuclear structure of one B. $b$. spinosus home range (50\% core area, thin line; $95 \%$ home range, thick line) and the distribution of locations. A marks the home range placement scale; B marks the space use within $95 \%$ home ranges, and C marks the space use within $50 \%$ core areas.

Bayesian regression model. We used a hierarchical logistic regression model within the Bayesian framework for modeling habitat selection by toads. Bayesian analyses of resource selection models account for variation among individuals (Gillies et al. 2006, Thomas et al. 2006, Hebblewhite and Merrill 2008). This is important, as individuals may differ in habitat selection due to variation in physiological state, tolerance to limiting resources, age (experience), and competitive ability.

The hierarchical logistic regression model fits a curve for each individual and then regards the curves of each individual as a further sample from which the overall relationship is estimated. The dependent variable $(y)$ was 0 when the corresponding grid cell was available and 1 when the grid cell was used by toads. Thus, for each individual $j(j=1, \ldots, J)$ and each observation $i(i$ $=1, \ldots, I)$, the dependent variable $y_{i, j}$ follows a Bernoulli distribution:

$$
y_{i, j} \sim \operatorname{Bern}\left(\mu_{i, j}\right) .
$$

The expected value $\mu_{i, j}$ is modeled by factors describing the grid cell using the logit link function in various combinations (Table 2, Appendix C). For simplicity, we present a model including the main effects only (Table 2 , model 10 ):

$$
\operatorname{logit}\left(\mu_{i, j}\right)=\alpha_{j} \mathrm{Pd}_{i, j}+\beta_{j} T_{i, j}+\gamma_{j, h} \mathrm{Ht}_{i, j}
$$

where $\mathrm{Pd}_{i, j}$ is prey density, $T_{i, j}$ is temperature, and $\mathrm{Ht}_{i, j}$ is habitat type (five levels: exposed gravel sediments, large wood deposits, dense pioneer vegetation, estab lished islands, edge of established islands) for individual $j$ at observation $i$. Because the habitat is categorical, there are different parameters for each habitat type. The individual slope parameters are then modeled with a normal distribution to estimate the population mean and variance:

$$
\begin{gathered}
\alpha_{j} \sim \mathcal{N}\left(\alpha, \sigma_{\alpha}^{2}\right) \\
\beta_{j} \sim \mathcal{N}\left(\beta, \sigma_{\beta}^{2}\right) \\
\gamma_{j, h} \sim \mathcal{N}\left(\gamma_{h}, \sigma_{\gamma, h}^{2}\right) .
\end{gathered}
$$

We were particularly interested in estimating the population slope parameters $\left(\alpha, \beta, \gamma_{h}\right)$. The variability $\left(\sigma_{\alpha}^{2}, \sigma_{\beta}^{2}, \sigma_{\gamma, h}^{2}\right)$ is a measure of how strongly the 
TABLE 2. Candidate models of habitat selection per species and spatial scale.

\begin{tabular}{|c|c|c|}
\hline Model & Covariates & Explanation \\
\hline 1 & $\begin{array}{l}\mathrm{Pd}+T+\mathrm{Ht}+(\mathrm{Pd} \times T)+(\mathrm{Pd} \times \mathrm{Ht})+(T \times \mathrm{Ht}) \\
\quad+(\mathrm{Pd} \times T \times \mathrm{Ht})\end{array}$ & $\begin{array}{l}\text { full model, all main factors and their interactions } \\
\text { important }\end{array}$ \\
\hline 2 & $\mathrm{Pd}+T+\mathrm{Ht}+(\mathrm{Pd} \times T)+(\mathrm{Pd} \times \mathrm{Ht})+(T \times \mathrm{Ht})$ & $\begin{array}{l}\text { three way interaction of prey density, temperature, } \\
\text { and habitat type not important }\end{array}$ \\
\hline 3 & $\mathrm{Pd}+T+\mathrm{Ht}+(\mathrm{Pd} \times T)+(\mathrm{Pd} \times \mathrm{Ht})$ & $\begin{array}{l}\text { interactions of prey density and temperature, and prey } \\
\text { density with habitat type important }\end{array}$ \\
\hline 4 & $\mathrm{Pd}+T+\mathrm{Ht}+(\mathrm{Pd} \times T)+(T \times \mathrm{Ht})$ & $\begin{array}{l}\text { interactions of prey density and temperature, and } \\
\text { temperature with habitat type important }\end{array}$ \\
\hline 5 & $\mathrm{Pd}+T+\mathrm{Ht}+(\mathrm{Pd} \times \mathrm{Ht})$ & interaction of prey density with habitat type important \\
\hline 6 & $\mathrm{Pd}+T+\mathrm{Ht}+(T \times \mathrm{Ht})$ & interaction of temperature with habitat type important \\
\hline 7 & $\mathrm{Pd}+\mathrm{Ht}+(\mathrm{Pd} \times \mathrm{Ht})$ & $\begin{array}{l}\text { interaction of prey density with habitat type important, } \\
\text { temperature not important }\end{array}$ \\
\hline 8 & $T+\mathrm{Ht}+(T \times \mathrm{Ht})$ & $\begin{array}{l}\text { interaction of temperature with habitat type important, } \\
\text { prey density not important }\end{array}$ \\
\hline 9 & $\mathrm{Pd}+T+\mathrm{Ht}+(\mathrm{Pd} \times T)$ & interaction of prey density and temperature important \\
\hline 10 & $\mathrm{Pd}+T+\mathrm{Ht}$ & all main factors without interactions important \\
\hline 11 & $\mathrm{Pd}+\mathrm{Ht}$ & prey density and habitat type important \\
\hline 12 & $T+\mathrm{Ht}$ & temperature and habitat type important \\
\hline 13 & $\mathrm{Ht}$ & habitat type important (null model) \\
\hline 14 & $\mathrm{Pd}+T+(\mathrm{Pd} \times T)$ & habitat type not important \\
\hline 15 & $\mathrm{Pd}+T$ & habitat type not important \\
\hline 16 & $\mathrm{Pd}$ & habitat type not important \\
\hline 17 & $T$ & habitat type not important \\
\hline
\end{tabular}

Notes: For models 18 , due to increasing model complexity, some parameters did not fully converge among three independent chains, but parameter estimates were consistent when models were fitted repeatedly. Abbreviations are: $\mathrm{Pd}, \log (\operatorname{prey}$ density); $T$, temperature; Ht, habitat type (five levels).

individuals differed regarding the preference for specific habitat characteristics. For a more detailed description of hierarchical models we refer readers to Gelman and Hill (2007). We specified noninformative priors for all parameters to be estimated. We used $N(0,0.001)$ priors for the slope parameters and, following Gelman (2005), uniform priors $U(0,100)$ for the variance parameters.

To calculate the posterior distributions of the param eters of interest, we used Markov chain Monte Carlo simulations implemented in WinBUGS software (Lunn et al. 2000) that we executed from R (R Development Core Team 2005) with the package R2WinBUGS (Sturtz et al. 2005). We ran three independent chains and checked the convergence using the Brooks Rubin Gel man diagnostic (Brooks and Gelman 1998). Conver gence usually was obtained quickly. For each candidate model, we ran three chains with 80000 iterations, discarded the first 25000 iterations, and saved every 10th sample. The explanatory factors were all standard ized (mean $=0, \mathrm{SD}=1$ ) prior to analysis.

\section{Model selection strategy}

Model selection was performed in two steps. First, we evaluated how each species responded to factors by modeling habitat selection separately for each species and spatial scale. Seventeen models were fit per species and scale, each reflecting a hypothesis (Table 2). The most complex model included habitat type, prey density, temperature, and all interactions among these factors (model 1). The simplest models included single factors (models 10 13, 15 16). Using the best model (deviance information criterion score $=0$ ) we predicted habitat selection separately for each species to graphically explore which habitat types were preferred and how species respond to varying levels of prey density and temperature within a given habitat type.

In the second step, we explored whether resource selection was species specific using the pooled data of both species. We therefore formulated a further set of seven candidate models based on the model that best fit our data from the first step (Appendix C). These models included the additive and interactive effects of the factor species with all factors in the best selected model out of the first step. Better support of models including interactive effects of species with prey density, temper ature, and/or habitat type than models without these interactions would provide evidence for differential resource selection.

The graphical output of predicted habitat selection (the first step) and the model selection results that include factor species as a factor (the second step) allowed us to evaluate the potential for differential resource selection. The graphs are illustrative while the model selection results provide statistical evidence for differential resource selection. For brevity, we show graphical results and refer to appendices for detailed model results.

\section{Results}

\section{Composition of floodplain habitat}

Both species preferred the same habitat types when placing home ranges within the floodplain, except that B. viridis avoided established islands (Table 1). Large wood deposits were most preferred and provided the lowest temperature of all habitat types (Table 1). 
TABLE 3. Model selection results for predicting habitat selection separately per species and spatial scale, sorted after the deviance information criterion scores $(\triangle \mathrm{DIC})$.

\begin{tabular}{|c|c|c|c|c|c|c|c|c|c|}
\hline \multicolumn{5}{|c|}{ Bufo bufo spinosus } & \multicolumn{5}{|c|}{ Bufo viridis } \\
\hline Model & DEV & $\mathrm{pD}$ & $\Delta \mathrm{DIC}$ & Weights & Model & DEV & $\mathrm{pD}$ & $\Delta \mathrm{DIC}$ & Weights \\
\hline \multicolumn{10}{|c|}{ Home range placement within floodplain } \\
\hline 1 & 236 & 58 & 0.0 & 0.975 & 1 & 1076 & 89 & 0.0 & 0.512 \\
\hline 2 & 245 & 55 & 7.3 & 0.025 & 2 & 1079 & 86 & 0.1 & 0.487 \\
\hline 4 & 277 & 55 & 38.8 & $3.7 \times 10^{9}$ & 4 & 1097 & 82 & 15.0 & $2.8 \times 10^{4}$ \\
\hline \multicolumn{10}{|c|}{ Space use within $95 \%$ home range } \\
\hline 1 & 1876 & 148 & 0.0 & 0.980 & 1 & 1199 & 146 & 0.0 & 0.782 \\
\hline 2 & 1889 & 142 & 7.8 & 0.020 & 2 & 1207 & 141 & 2.5 & 0.218 \\
\hline 4 & 1931 & 135 & 41.7 & $8.5 \times 10^{10}$ & 4 & 1245 & 135 & 35.1 & $1.9 \times 10^{8}$ \\
\hline \multicolumn{10}{|c|}{ Space use within $50 \%$ core area } \\
\hline 1 & 975 & 83 & 0.0 & 0.840 & 2 & 970 & 100 & 0.0 & 0.963 \\
\hline 3 & 989 & 74 & 4.3 & 0.097 & 1 & 974 & 103 & 7.2 & 0.026 \\
\hline 2 & 986 & 78 & 5.8 & 0.046 & 4 & 982 & 96 & 9.0 & 0.011 \\
\hline
\end{tabular}

Notes: For brevity, the three models that provided the best fit to the data are shown (see Appendix D for full model table). The best fit model appears in boldface. See Table 2 for descriptions of models. All factors were standardized prior to analysis. Abbreviations are: DEV, deviance; pD, effective number of parameters; weights, DIC model weights. The $\triangle D I C$ is the difference in DIC between any model in the set and the best model. The smaller the $\triangle \mathrm{DIC}$, the more similar the fit compared with the best model (chosen as the model with $\Delta$ DIC 0 ). The top ranked model with $\triangle$ DIC 0 best approximates the data (Spiegelhalter et al. 2002). If model weights were equally distributed across models, uncertainty in model selection would be maximal.

Established islands provided the highest prey density of all habitat types. Prey density was slightly higher and temperature significantly lower within than outside home ranges (mean $\log$ (prey density), B. b. spinosus, within home range, $0.175 \mathrm{prey} / \mathrm{m}^{2}$, outside home range, 0.145 prey $/ \mathrm{m}^{2}, t=1.243, \mathrm{df}=27, P=0.224 ; B$. viridis, within home range, $0.198 \mathrm{prey} / \mathrm{m}^{2}$, outside home range, 0.148 prey $/ \mathrm{m}^{2}, t=1.655$, df $=31, P=0.107$; mean temperature, B. b. spinosus, within home range, $33.8^{\circ} \mathrm{C}$, outside home range, $42.8^{\circ} \mathrm{C}, t=17.353$, df $=29, P<$ $0.001 ; B$. viridis, within home range, $36.4^{\circ} \mathrm{C}$, outside home range, $\left.42.6^{\circ} \mathrm{C}, t=9.558, \mathrm{df}=37, P<0.001\right)$. Prey density and temperature were uncorrelated at the level of home range placement ( $B . b$. spinosus, $r=0.076 ; B$. viridis, $r=0.088$ ), within $95 \%$ home ranges $(B . b$. spinosus, $r=0.141 ; B$. viridis, $r=0.099)$, and within $50 \%$ core areas (B. b. spinosus, $r=0.23$; B. viridis, $r=0.042$ ).

\section{Home range placement within the floodplain}

For both species, the most complex model (habitat type, temperature, prey density, and all interactions) was the best fit to the data (model 1; Table 3, Appendix D). For $B$. viridis, a model excluding the three way interaction habitat type $\times$ prey density $\times$ temperature (model 2) performed as equally well as the most complex model as indicated by the similar model weights (Table 3). Hence, all the three factors, habitat type, prey density, and temperature, were important at the home range placement scale, in line with our expectation. When the data from both species were jointly analyzed, the selection procedure favored a model that included habitat type, prey density, temperature, species, and the interaction species $\times$ habitat type (model 22, weights $=$ 0.756; Appendix E). The second ranked model included the interactive effects of species with prey density and temperature, in addition to all other factors in the top ranked model (model 23, weights $=0.213$ ). The two top ranked models together accounted for $96.9 \%$ of the model weights, thereby providing evidence for species specific resource selection at the home range placement scale.

Both species clearly placed home ranges in areas containing any habitat type except exposed gravel sediments (Fig. 2). Though all factors were important in determining home range placement (Table 3), habitat type specific selection probabilities varied little in response to prey density and temperature (Figs. 3a, b, $4 \mathrm{~b}$, and $5 \mathrm{a}, \mathrm{b})$. An exception was that $B$. b. spinosus placed home ranges in areas that contained dense pioneer vegetation with high prey density (Fig. 4a). The effects of habitat types therefore outweighed the effects of prey density and temperature at the home range placement scale (Fig. 2; Appendix F). For habitat types that were most avoided by $B$. b. spinosus (exposed gravel) and $B$. viridis (exposed gravel, established islands) (Table 1, Fig. 2), see Appendices G and H.

\section{Space use within $95 \%$ home ranges}

Similarly to home range placement, the most complex model (habitat type, temperature, prey density, and all interactions) was the best fit for both species (model 1; Table 3, Appendix D). For B. viridis, the distribution of model weights indicated model selection uncertainty with model 1 being $\sim 3.6$ times better supported than model 2 (evidence ratio, $0.782 / 0.218=3.6$ ). Hence, all three main factors, as well as their interactive effects, were important in the explanation of space use within $95 \%$ home ranges, in contrast to our expectation. The model selection when both species were combined favored the most complex model (model 23, weights $=$ 
a) Home range placement within floodplain
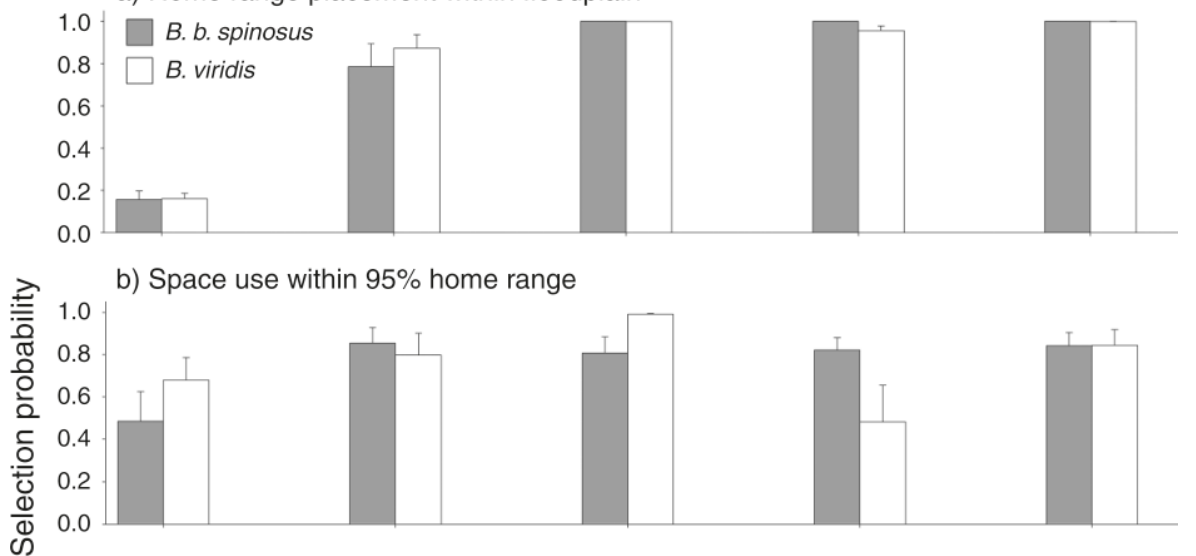

c) Space use within $50 \%$ core area

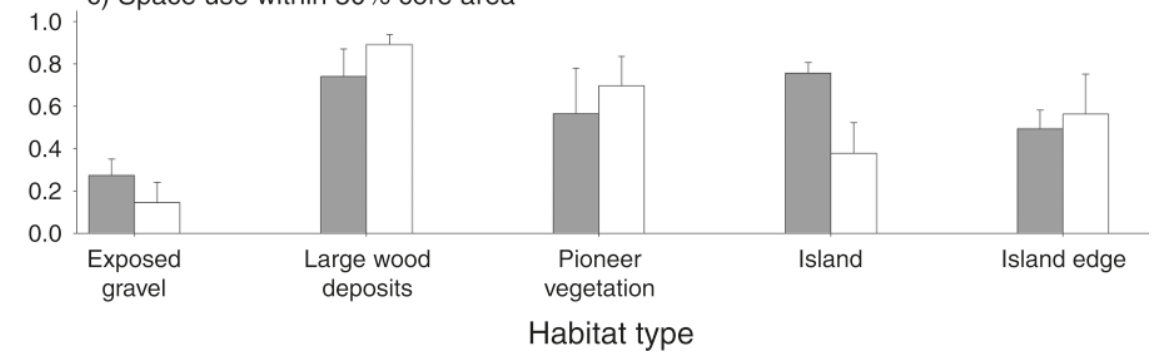

FIG. 2. Predicted selection probabilities (mean + SE), separately by habitat type, scale, and species: the European common toad (Bufo bufo spinosus) and the green toad (B. viridis). The model that best explained habitat selection was used to predict selection probabilities (Table 3; Appendix D). Mean prey density and temperature were used for calculating the predictions.

0.676; Appendix F). This model included the four main effects as well as the interactions of species with prey density, temperature, and habitat type, thereby provid ing evidence for differential resource selection within 95\% home ranges.

Both species preferred large wood deposits, dense pioneer vegetation, and island edges, but differed in their use of exposed gravel sediments and established islands within 95\% home ranges (Fig. 2). Bufo b. spinosus preferentially used large wood deposits with high prey density, whereas $B$. viridis used large wood deposits independent of prey and temperature (Fig. 3c, d). Bufo b. spinosus used dense pioneer vegetation with high prey density, whereas $B$. viridis used the same habitat type largely independent of prey density or temperature (Fig. $4 \mathrm{c}, \mathrm{d})$. Bufo b. spinosus used island edges with lower temperatures (Fig. 5c), whereas B. viridis used island edges with high prey density (Fig. 5d).

\section{Space use within $50 \%$ core areas}

For B. b. spinosus the most complex model (model 1) was favored by the selection procedure, while for $B$. viridis, model 2 was the best fit (Table 3, Appendix D). Model 2 differed from model 1 by excluding the three way interaction habitat type $\times$ prey density $\times$ temper ature (Table 2). Hence, space use at the smallest spatial scale depended on the interactive effects of habitat type, prey density, and temperature, which was against our expectation. As for larger spatial scales, the analysis of both species combined favored the most complex model (model 23, weights $=0.941 ;$ Appendix E). This provides evidence for differential selection of prey density and temperature within shared habitat types.

Large wood deposits were highly preferred by both species within $50 \%$ core areas (Fig. 2). Established islands were preferred by $B$. b. spinosus but avoided by B. viridis. Bufo b. spinosus randomly used dense pioneer vegetation and the island edge. Bufo viridis preferred dense pioneer vegetation (Fig. 2). Within core areas, the effects of habitat types were lowest, as evidenced by selection probabilities that are closer to 0.5 than at the larger spatial scale (Fig. 2). Large wood deposits were preferentially used by $B . b$. spinosus when they had high prey density, whereas those with low temperatures were preferred by $B$. viridis (Fig. 3e,f). Dense pioneer vegetation with high prey density and high temperature were preferred by B. b. spinosus (Fig. 4e), while B. viridis preferred low temperature rather than high prey density in this habitat type (Fig. 4f). Bufo b. spinosus used the coolest island edges with lowest prey density (Fig. 5e), whereas Bufo viridis preferentially used the coolest island edges with highest prey density (Fig. 5f).

\section{DisCUSSION}

Differential habitat selection is a central component in the evolution of species because it determines distribu 


\section{B. b. spinosus}

\section{B. viridis}
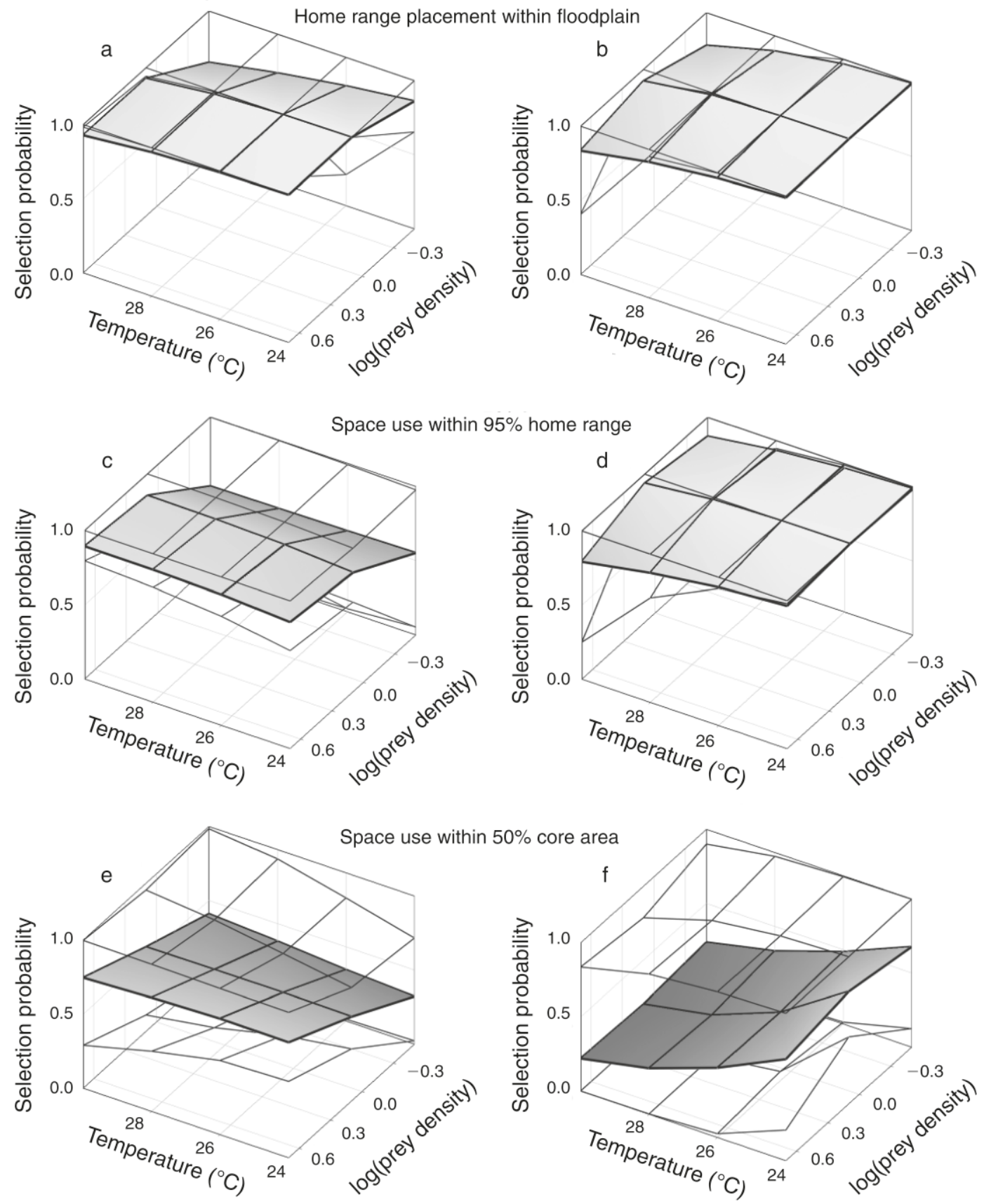

FIG. 3. Predicted selection probabilities in relation to the large wood deposits habitat type, $\log ($ prey density), and temperature, separately by scale and species: the European common toad (Bufo bufo spinosus) and the green toad (B. viridis). The model that best explained habitat selection was used to predict selection probabilities (Table 3; Appendix D). Predictions were done for constant low ( 0.5), intermediate (0.1), and high $(0.7) \log \left(\right.$ prey density), as well as for 14 temperature values ranging from $20^{\circ} \mathrm{C}$ to $46^{\circ} \mathrm{C}$. Prey density was measured as number per square meter. Shaded areas are mean selection probabilities, whereas transparent areas indicate the lower and upper $95 \%$ confidence interval. If there is no selection, the selection probability $(\operatorname{Pr})$ is 0.5 ; if there is avoidance, $\operatorname{Pr}<0.5$; and if there is preference, $\operatorname{Pr}>0.5$. When the selection surface parallels the $x$ and $y$ axes, selection is independent of prey and temperature. 


\section{B. viridis}
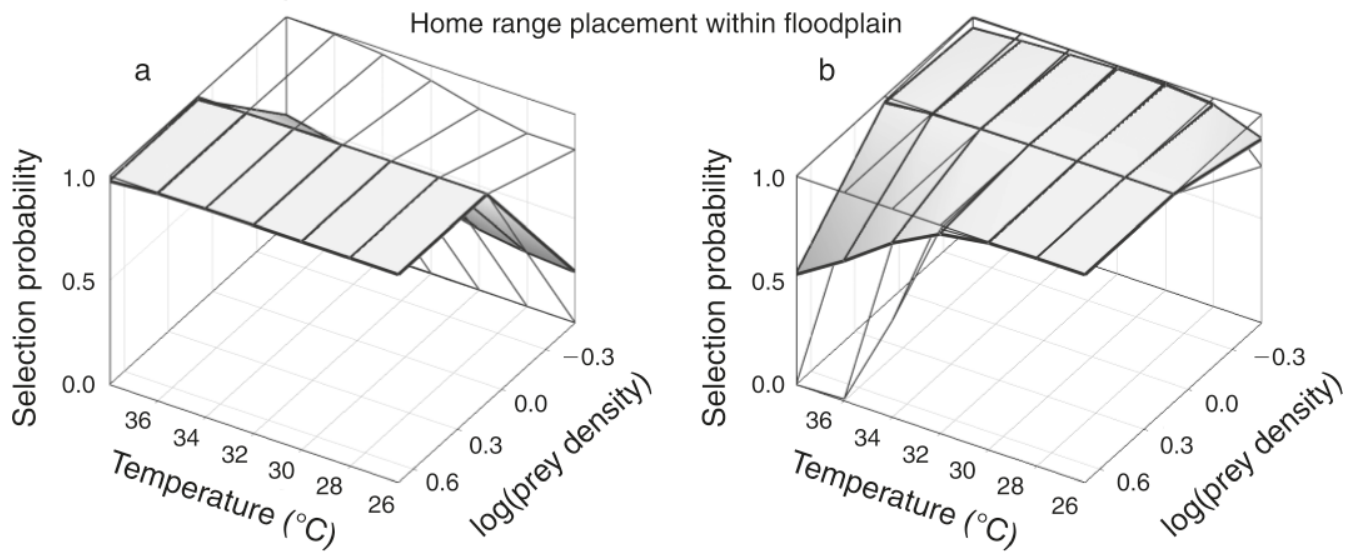
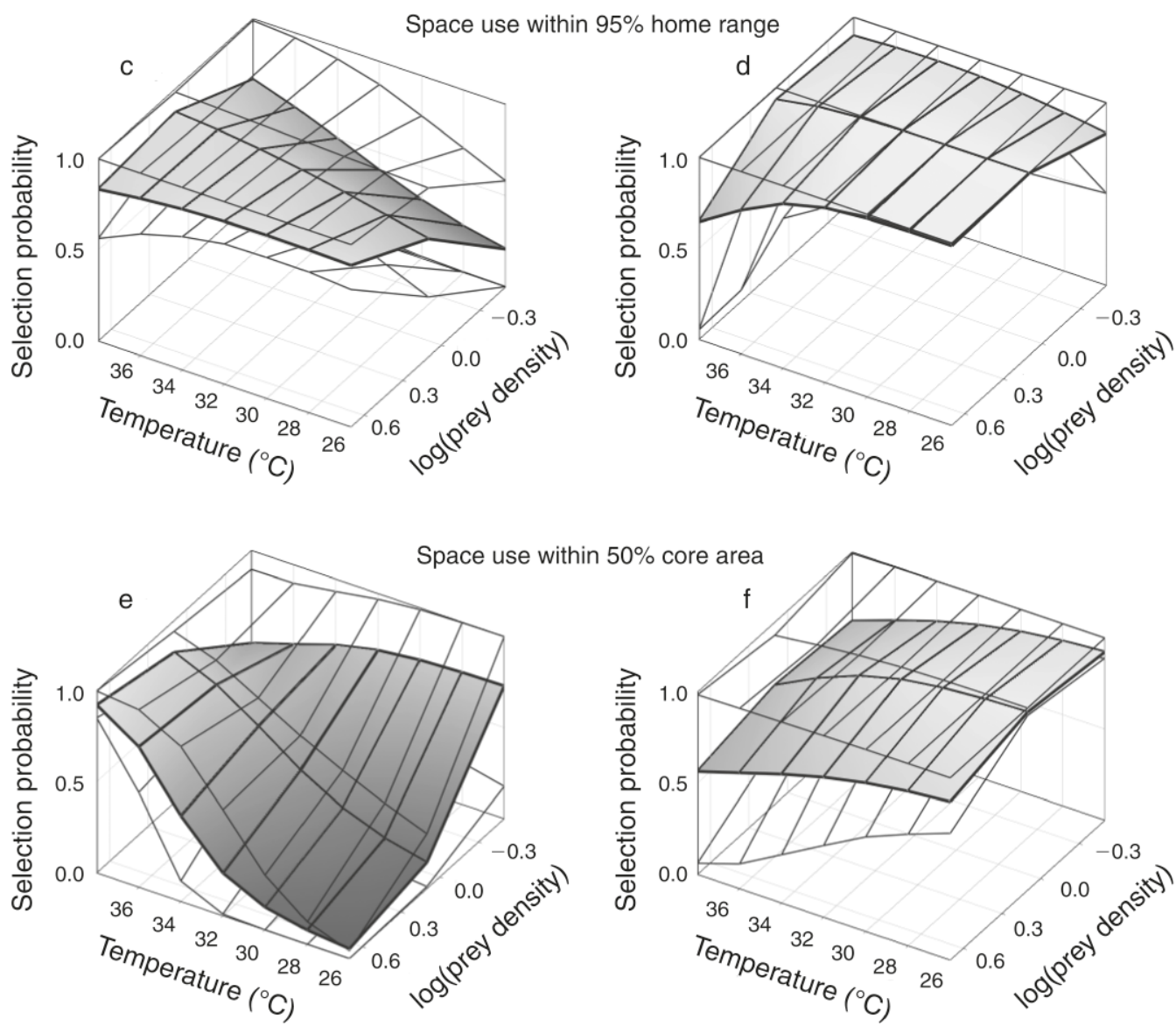

FIG. 4. Predicted selection probabilities in relation to the dense pioneer vegetation habitat type, $\log ($ prey density), and temperature, separately by scale and species: the European common toad (Bufo bufo spinosus) and the green toad (B. viridis). See Fig. 3 for details.

tion and abundance and allows species coexistence (MacArthur et al. 1966, Werner et al. 1983). Nonethe less, differential habitat selection among sympatric species rarely has been quantified in relation to the joint impacts of multiple resources at the spatial scales at which animals operate (Anthony and Smith 1977,
Bourget et al. 2007, Gilbert et al. 2008). We found that habitat type, prey density, temperature, and all interac tions among these factors determined home range placement as well as space use within home ranges. We conclude that these two amphibians perceive the distribution of habitat types as well as gradients in prey 


\section{B. b. spinosus}

\section{B. viridis}
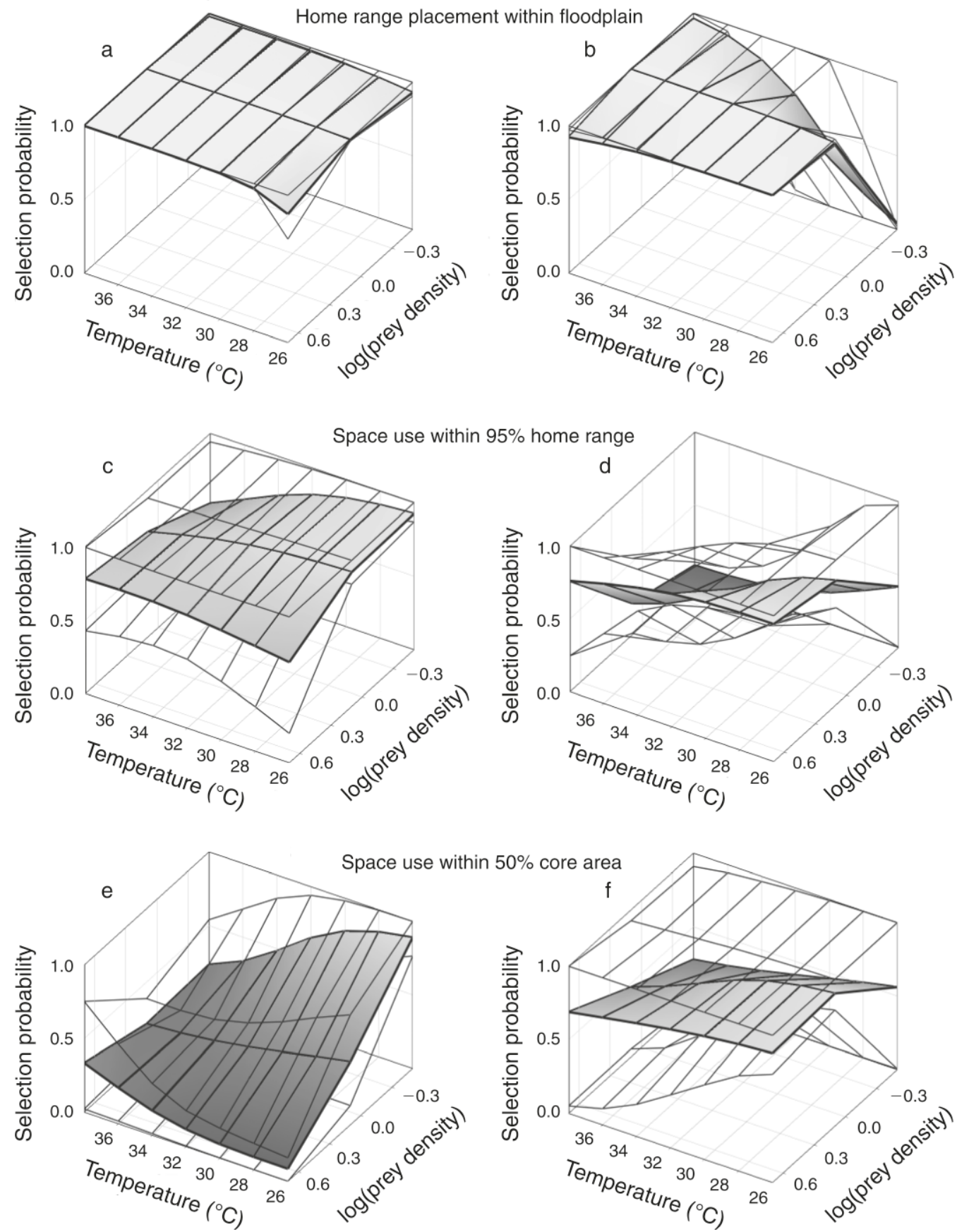

FIG. 5. Predicted selection probabilities in relation to the island edge habitat type, $\log$ (prey density), and temperature, separately by scale and species: the European common toad (Bufo bufo spinosus) and the green toad (B. viridis). See Fig. 3 for details.

density and temperature at all spatial scales. Moreover, we found that the two species differentially used a biotic resource (prey density) and an abiotic condition (temperature) within shared habitat types across spatial scales, thereby providing an explanation why two species coexist in terrestrial summer habitats.

\section{Placement and use of terrestrial home ranges}

As expected, we found that home range placement depended on habitat type, prey density, temperature, and the interactive effects among these factors (Table 3), resulting in slightly higher prey density and significantly lower temperature within than outside home ranges. 
Home range placement therefore determined resource availability and conditions within home ranges (Orians and Wittenberger 1991) and is most probably done such that all the toad's food and refuge requirements are met during the terrestrial summer period. Whether a factor becomes limiting at small spatial scales is hence influenced by the placement of home ranges, which is why home range placement is considered most impor tant (Rettie and Messier 2000). At the home range placement scale, the habitat type specific selection prob abilities did not vary strongly in relation to prey density and temperature (Figs. 3 5), suggesting that prey density and temperature were less important for home range placement than habitat type (Fig. 2; Appendix F). Our results support the idea that broad landscape features, such as available habitat types, have a dominating effect on home range placement because they indicate availability of resources and conditions (Lack 1940, MacArthur et al. 1966, Cody 1981).

Space use within 95\% home ranges and within $50 \%$ core areas was governed by the same factors seen for home range placement, which was in contrast to our expectation (Table 3). Thus, both species perceived the distribution of habitat types as well as gradients in prey density and temperature at all spatial scales. Within core areas, the effects of habitat types were lowest (Fig. 2). Consequently, resources and conditions most strongly affect space use and hence the distribution of species at small spatial scales (Figs. 3 5). This has been noted elsewhere and appears to be a general pattern in habitat selection (Rettie and Messier 2000, Dussault et al. 2005, Chalfoun and Martin 2007). The environmental infor mation obtained by animals at small spatial scales is theoretically maximal (Orians and Wittenberger 1991) because individuals can sample the entire area. Conse quently, knowledge about resource patches must de crease with increasing distance between patches (Fauchald 1999, Roshier et al. 2008). Our results suggest that the selection of food as well as refuge (from predators and desiccation) at small spatial scales is facilitated by the accumulation of environmental infor mation by individuals.

\section{Differential use of shared habitat types between species}

Both species generally preferred the same habitat types, although B. viridis avoided established islands at the two smaller spatial scales (Fig. 2). Habitat types that were preferred by both species, however, were used differentially in relation to prey density and temperature by both species at all spatial scales (Figs. 3 5; Appen dices D, E, F, G, and $\mathrm{H}$ ). Our findings suggest niche differentiation through differential resource selection within shared habitat types as a mechanism that stabilizes the coexistence of $B$. b. spinosus and B. viridis in terrestrial summer habitats. Similarly, scale depen dent niche differentiation has been found recently in mosquito larvae (Gilbert et al. 2008).
The differential use of shared habitat types likely reflects the regulation of different behaviors such as feeding, thermoregulation, and/or avoidance of preda tors (Figs. 3 5). For example, B. b. spinosus likely used large wood deposits within core areas for feeding while B. viridis selected large wood deposits most probably for thermoregulation (Fig. 3). Large wood deposits were clearly preferred by both species and provided lowest temperature but also low prey density. For B. viridis, large wood deposits are often the only habitat type in a matrix of exposed gravel sediment and therefore are crucial in providing refuge from high temperatures and predators (Indermaur et al. 2009). The fact that the same habitat type was used to regulate either foraging behavior or thermoregulation suggests that the mecha nistic basis of niche differentiation might be due to differences in physiological requirements (Denton and Beebee 1994).

We would have expected that selection probabilities are highest when prey density is high and temperature low; however, this was not always the case (Figs. 4e and 5e). An explanation for this phenomenon might be that high prey density or low temperature correlates with predation risk, which may affect habitat selection. We have no spatially explicit data on predation mortality. Anecdotal observations suggest that predation mortality is negligible (L. Indermaur, personal observation), most likely because the toads are not palatable. Nonetheless, a comprehensive understanding of habitat selection would require that habitat type specific predation mortality is also quantified.

\section{Conclusions}

The two sympatric amphibian species differentially used the same habitat types in relation to a biotic resource (prey density) and an abiotic condition (temperature) at all spatial scales. Thus, niche differen tiation through differential selection of resources and conditions at multiple spatial scales most probably stabilizes the coexistence of the two species in their terrestrial summer habitat. In other words, while one species used the same habitat type for foraging, the other used it for resting or both resting and foraging. Differential use of shared habitat types at multiple spatial scales can therefore reduce competition for prey and refuges, thereby facilitating coexistence and conse quently high species richness.

Our results demonstrate that the ecological relevance of factors varied with spatial scale (Rettie and Messier 2000, Beasley et al. 2007, Chalfoun and Martin 2007, Ciarniello et al. 2007) as well as species. Home range placement was primarily governed by broad habitat features (habitat type), while space use within home ranges was largely controlled by food resources and an abiotic condition (temperature). These results contradict the idea that broad scale movement patterns simply reflect the underlying resource distribution (Bennetts and Kitchens 2000, Eide et al. 2004). Rather, processes 
acting at large scales include a fixed behavioral response leading to movement patterns at small spatial scales. Consequently, species distributions and species richness likely result from processes operating at large and small scales. The scale specific movement patterns observed imply that orientation and decision making in animal ecology is behaviorally complex. As is often illustrated when animal dispersal and species distributions are modeled, movements are not random and do not arise from a predefined set of local decision rules (Pulliam et al. 1992, Gustafson and Gardener 1996). Instead, decision rules change with the amount of environmental information collected by the individual, with informa tion about resource availability decreasing with distance (Fauchald 1999). Thus, the integration of behavioral complexity in the modeling of dispersal and species distributions is needed.

Failure to view habitat selection as a spatially hierarchical process results in a simplified view of the behavioral requirements of animals. For example, the role of the core area for regulating resting and foraging behavior would have remained undetected by focusing only on the home range placement scale. Hence, an integral management of species should include informa tion from multiple spatial scales such as core areas, home ranges, and landscapes. At the landscape scale, increasing habitat availability most probably increases the landscape's connectivity, thereby facilitating the colonization of habitats. Within home ranges, refuge provisioning, for example by adding large wood deposits, seems most suitable to promote amphibians in terrestrial summer habitats. Large wood deposits are a key habitat type (Indermaur et al. 2009) even though it covers only a tiny fraction of the floodplain area. The availability of large wood deposits depends on an unconstrained channel, a natural flow regime, and a fringing riparian forest (Arscott et al. 2002, van der Nat et al. 2003). Flow regulation will reduce the availability of the most preferred habitat type. Consequently, species would either disappear or be forced to compete for resources in the remaining habitat types.

\section{ACKNOWLEDGMENTS}

We are grateful to Marianne Gehring and Wendelin Wehrle for field data collection, to Urs Richard for help with the raster data, and to Christopher Robinson and Michael Monaghan for language polishing. We especially thank Jonathan Rhodes and an anonymous reviewer for their comments and criticism that improved the manuscript. All methods applied conform to the ethical and animal care guidelines issued by national (Ministero dell'Ambiente e della Tutela del Territorio, Direzione per la Protezione della Natura, Roma) and regional (Direzione Centrale Risorse Agricole, Forestali e Naturali, Regione Friuli Venezia Giulia, Udine) authorities in Italy that kindly provided permits. The project was funded by the MAVA Foundation (Switzerland).

\section{Literature Cited}

Anthony, R. G., and N. S. Smith. 1977. Ecological relation ships between mule deer and white tailed deer in southeastern Arizona. Ecological Monographs 47:255 277.
Arscott, D. B., K. Tockner, D. van der Nat, and J. V. Ward. 2002. Aquatic habitat dynamics along a braided alpine river ecosystem (Tagliamento River, Northeast Italy). Ecosystems $5: 802814$.

Beasley, J. C., T. L. Devault, M. I. Retamosa, and O. E. J. Rhodes. 2007. A hierarchical analysis of habitat selection by raccoons in northern Indiana. Journal of Wildlife Manage ment 71:1125 1133 .

Bennetts, R. E., and W. M. Kitchens. 2000. Factors influencing movement probabilities of a nomadic food specialist: Proximate foraging benefits or ultimate gains from explora tion? Oikos 91:459 467.

Borger, L., N. Franconi, F. Ferretti, F. Meschi, G. De Michele, A. Gantz, and T. Coulson. 2006. An integrated approach to identify spatiotemporal and individual level determinants of animal home range size. American Naturalist 168:471 485.

Bourget, D., J. P. L. Savard, and M. Guillemette. 2007. Distribution, diet and dive behavior of Barrow's and common goldeneyes during spring and autumn in the St. Lawrence estuary. Waterbirds 30:230 240.

Brooks, S. P., and A. Gelman. 1998. General methods for monitoring convergence of iterative simulations. Journal of Computational and Graphical Statistics 7:434 455.

Burt, W. H. 1943. Territoriality and home range concepts as applied to mammals. Journal of Mammalogy 24:346 352.

Chalfoun, A. D., and T. E. Martin. 2007. Assessments of habitat preferences and quality depend on spatial scale and metrics of fitness. Journal of Applied Ecology 44:983 992.

Chesson, P. 2000. Mechanisms of maintenance of species diversity. Annual Review of Ecology and Systematics 31: 343366

Ciarniello, L. M., M. S. Boyce, D. R. Seip, and D. C. Heard. 2007. Grizzly bear habitat selection is scale dependent. Ecological Applications 17:1424 1440.

Clutton Brock, T. H., F. Guiness, and S. D. Albon. 1982. Red deer: behaviour and ecology of two sexes. University of Chicago Press, Chicago, Illinois, USA.

Cody, M. L. 1981. Habitat selection in birds: the roles of habitat structure, competitors, and productivity. BioScience 31:107 113 .

Denton, J. S., and T. J. C. Beebee. 1994. The basis of niche separation during terrestrial life between two species of toad (Bufo bufo and Bufo calamita): Competition or specialisation? Oecologia 97:390 398.

de Smith, M. J., M. F. Goodchild, and P. A. Longley. 2006. Geospatial analysis: a comprehensive guide to principles, techniques and software tools. Second edition. 〈http://www. spatialanalysisonline.com/>

Diamond, J. M. 1973. Distributional ecology of New Guinea birds. Science 179:759 769.

Dussault, C., J. P. Ouellet, R. Courtois, J. Huot, L. Breton, and H. Jolicoeur. 2005. Linking moose habitat selection to limiting factors. Ecography 28:619 628.

Eide, N. E., J. U. Jepsen, and P. Prestrud. 2004. Spatial organization of reproductive Arctic foxes Alopex lagopus: responses to changes in spatial and temporal availability of prey. Journal of Animal Ecology 73:1056 1068.

Engler, R., A. Guisan, and L. Rechsteiner. 2004. An improved approach for predicting the distribution of rare and endangered species from occurrence and pseudo absence data. Journal of Applied Ecology 41:263 274.

Fauchald, P. 1999. Foraging in a hierarchical patch system. American Naturalist 153:603 613.

Gause, G. F. 1934. The struggle for existence. Williams and Wilkins, Baltimore, Maryland, USA.

Gelman, A. 2005. Prior distributions for variance parameters in hierarchical models. Bayesian Analysis 1:1 19.

Gelman, A., and J. Hill. 2007. Data analysis using regression and multilevel/hierarchical models. Cambridge University Press, New York, New York, USA. 
Giacoma, C., and S. Castellano. 2006. Bufo bufo and Bufo viridis. Pages 302311 in R. Sindaco, G. Doria, E. Razzetti, and F. Bernini, editors. Atlante degli anfibi e dei rettili d'Italia. Societas Herpetologica Italica, Edizione Polistampa, Firenze, Italy.

Gilbert, B., D. S. Srivastava, and K. R. Kirby. 2008. Niche partitioning at multiple scales facilitates coexistence among mosquito larvae. Oikos 117:944 950.

Gillies, C. S., M. Hebblewhite, S. E. Nielsen, M. A. Krawchuk, C. L. Aldridge, J. L. Frair, D. J. Saher, C. E. Stevens, and C. L. Jerde. 2006. Application of random effects to the study of resource selection by animals. Journal of Animal Ecology 75:887 898 .

Gustafson, E. J., and R. H. Gardner. 1996. The effect of landscape heterogeneity on the probability of patch coloni zation. Ecology 77:94 107.

Hairston, N. G. 1951. Interspecies competition and its probable influence upon the vertical distribution of Appalachian salamanders of the genus Plethodon. Ecology 32:266 274.

Hardin, G. 1960. The competitive exclusion principle. Science 131:1292 1297

Harper, E. B., T. A. G. Rittenhouse, and R. D. Semlitsch. 2008. Demographic consequences of terrestrial habitat loss for pool breeding amphibians: predicting extinction risks associ ated with inadequate size of buffer zones. Conservation Biology 22:1205 1215.

Hebblewhite, M., and E. Merrill. 2008. Modelling wildlife human relationships for social species with mixed effects resource selection models. Journal of Applied Ecology 45: 834844.

Hutchinson, G. E. 1957. Concluding remarks. Cold Spring Harbor Symposia on Quantitative Biology 22:415 427.

Indermaur, L., M. Gehring, W. Wehrle, K. Tockner, and B. Naef Daenzer. 2009. Behavior based scale definitions for determining individual space use: requirements of two amphibians. American Naturalist 173:60 71.

Indermaur, L., B. R. Schmidt, and K. Tockner. 2008. Effect of transmitter mass and tracking duration on body mass change of two anuran species. Amphibia Reptilia 29:263 269.

Johnson, D. H. 1980. The comparison of usage and availability measurements for evaluating resource preference. Ecology 61:65 71 .

Kenward, R. E., and K. H. Hodder. 1996. Ranges 7 software for analysing animal location data. Institute of Terrestrial Ecology, Wareham, UK.

Kie, J. G., R. T. Bowyer, M. C. Nicholson, B. B. Boroski, and E. R. Loft. 2002. Landscape heterogeneity at differing scales: effects on spatial distribution of mule deer. Ecology 83:530 544.

Lack, D. 1940. Habitat selection and speciation in birds. British Birds 34:80 84.

Levins, R. 1968. Evolution in changing environments. Prince ton University Press, Princeton, New Jersey, USA.

Lunn, D. J., A. Thomas, N. Best, and D. Spiegelhalter. 2000. WinBUGS a Bayesian modelling framework: concepts, structure, and extensibility. Statistics and Computing 10: 325337.

MacArthur, R. H., and R. Levins. 1967. Limiting similarity convergence and divergence of coexisting species. American Naturalist 101:377 385.

MacArthur, R. H., H. Recher, and M. L. Cody. 1966. On the relation between habitat selection and bird diversity. American Naturalist 100:319 332

Marzluff, J. M., S. T. Knick, and J. J. Millspaugh. 2001. High tech behavioral ecology: modeling the distribution of animal activities to better understand wildlife space use and resource selection. Pages 309326 in J. J. Millspaugh and J. M. Marzluff, editors. Radio tracking an animal population. Academic Press, San Diego, California, USA.

Morris, D. W. 1987. Ecological scale and habitat use. Ecology 68:362 369
Nikula, A., S. Heikkinen, and E. Helle. 2004. Habitat selection of adult moose Alces alces at two spatial scales in central Finland. Wildlife Biology 10:121 135.

Orians, G. H., and J. F. Wittenberger. 1991. Spatial and temporal scales in habitat selection. American Naturalist 137: 2949.

Petts, G. E., A. M. Gurnell, A. J. Gerrard, D. M. Hannah, B. Hansford, I. Morrissey, P. J. Edwards, J. Kollmann, J. V. Ward, K. Tockner, and B. P. G. Smith. 2000. Longitudinal variations in exposed riverine sediments: a context for the ecology of the Fiume Tagliamento, Italy. Aquatic Conserva tion: Marine and Freshwater Ecosystems 10:249 266.

Pianka, E. R. 1969. Sympatry of desert lizards (Ctenotus) in Western Australia. Ecology 50:1012 1030.

Pinaud, D., and H. Weimerskirch. 2005. Scale dependent habitat use in a long ranging central place predator. Journal of Animal Ecology 74:852 863 .

Powell, R. A. 2000. Animal home ranges and territories and home range estimators. Pages 65110 in L. Boitani and T. K. Fuller, editors. Research techniques in animal ecology: controversies and consequences. Columbia University Press, New York, New York, USA.

Pulliam, H. R., J. B. Dunning, and J. G. Liu. 1992. Population dynamics in complex landscapes: a case study. Ecological Applications 2:165 177.

R Development Core Team. 2005. R: a language and environment for statistical computing. R Foundation for Statistical Computing, Vienna, Austria.

Rathbun, G. B., and T. G. Murphey. 1996. Evaluation of a radio belt for ranid frogs. Herpetological Review 27:187 189.

Rettie, W. J., and F. Messier. 2000. Hierarchical habitat selection by woodland caribou: its relationship to limiting factors. Ecography 23:466 478 .

Richards, S. J., U. Sinsch, and R. A. Alford. 1994. Radio tracking. Pages 155157 in W. R. Heyer, M. A. Donnelly, R. W. McDiarmid, L. C. Hayek, and M. S. Foster, editors. Measuring and monitoring biological diversity: standard methods for amphibians. Smithsonian Institution Press, Washington, D.C., USA.

Rosenzweig, M. L. 1991. Habitat selection and population interactions: the search for mechanism. American Naturalist 137:5 28

Roshier, D. A., V. A. J. Doerr, and E. D. Doerr. 2008. Animal movement in dynamic landscapes: interaction between behavioural strategies and resource distributions. Oecologia 156:465 477.

Schmidt, B. R., R. Feldmann, and M. Schaub. 2005. Demographic processes underlying population growth and decline in Salamandra salamandra. Conservation Biology 19: 11491156

Schwarzkopf, L., and R. A. Alford. 1996. Desiccation and shelter site use in a tropical amphibian: comparing toads with physical models. Functional Ecology 10:193 200.

Seebacher, F., and R. A. Alford. 2002. Shelter microhabitats determine body temperature and dehydration rates of a terrestrial amphibian (Bufo marinus). Journal of Herpetology $36: 6975$

Spiegelhalter, D. J., N. G. Best, B. R. Carlin, and A. van der Linde. 2002. Bayesian measures of model complexity and fit. Journal of the Royal Statistical Society Series B 64:583 616.

Sturtz, S., U. Ligges, and A. Gelman. 2005. R2WinBUGS: a package for running WinBUGS from R. Journal of Statistical Software 12:1 16.

Thomas, D. L., D. Johnson, and B. Griffith. 2006. A Bayesian random effects discrete choice model for resource selection: population level selection inference. Journal of Wildlife Management 70:404 412 .

Tockner, K., I. Klaus, C. Baumgartner, and J. V. Ward. 2006. Amphibian diversity and nestedness in a dynamic floodplain river (Tagliamento, NE Italy). Hydrobiologia 565:121 133. 
Tockner, K., J. V. Ward, D. B. Arscott, P. J. Edwards, J. Kollmann, A. M. Gurnell, G. E. Petts, and B. Maiolini. 2003. The Tagliamento River: a model ecosystem of European importance. Aquatic Sciences 65:239 253.

van der Nat, D., K. Tockner, P. J. Edwards, and J. V. Ward. 2003. Large wood dynamics of complex Alpine river floodplains. Journal of the North American Benthological Society 22:35 50 .

Walti, M. O., and H. U. Reyer. 2007. Food supply modifies the trade off between past and future reproduction in a sexual parasite host system (Rana esculenta, Rana lessonae). Oeco logia 152:415 424
Ward, J. V., K. Tockner, P. J. Edwards, J. Kollmann, G. Bretschko, A. M. Gurnell, G. E. Petts, and B. Rosaro. 1999. A reference river system for the Alps: the "Fiume Taglia mento." Regulated Rivers: Research and Management 15: 6375.

Werner, E. E., G. G. Mittelbach, D. J. Hall, and J. F. Gilliam. 1983. Experimental tests of optimal habitat use in fish: the role of relative habitat profitability. Ecology 64:1525 1539 .

Whittaker, R. H. 1967. Gradient analysis of vegetation. Biological Reviews of the Cambridge Philosophical Society 42:207 264.

Wiens, J. A. 1973. Pattern and process in grassland bird communities. Ecological Monographs 43:237 270 .

\section{APPENDIX A}

View of the study site from Monte Ragogna (Ecological Archives E090 240 A1).

\section{APPENDIX B}

Map of the study site (Ecological Archives E090 240 A2).

\section{APPENDIX C}

Candidate models used to evaluate the potential for differential resource selection within shared habitat type (Ecological Archives E090 240 A3).

\section{APPENDIX D} A4).

Model selection results for predicting habitat selection separately per species and spatial scale (Ecological Archives E090 240

\section{APPENDIX E}

Model selection results for exploring the potential for differential resource selection within shared habitat types (Ecological Archives E090 240 A5).

\section{APPENDIX F} A6).

Effect sizes and measures of precision for the 23 parameters of the best selected model (Table 3) (Ecological Archives E090 240

\section{APPENDIX G}

Predicted selection probabilities in relation to the exposed gravel sediments habitat type, $\log ($ prey density), and temperature (Ecological Archives E090 240 A7).

\section{APPENDIX H}

Predicted selection probabilities in relation to the established islands habitat type, $\log$ (prey density), and temperature (Ecological Archives E090 240 A8). 


\section{Ecological Archives E090-240-A1}

Lukas Indermaur, Thomas Winzeler, Benedikt R. Schmidt, Klement Tockner, and Michael Schaub. 2009. Differential resource selection within shared habitat types across spatial scales in sympatric toads. Ecology 90:3430-3444.

Appendix A. View of the study site from Monte Ragogna (L. Indermaur 2008).

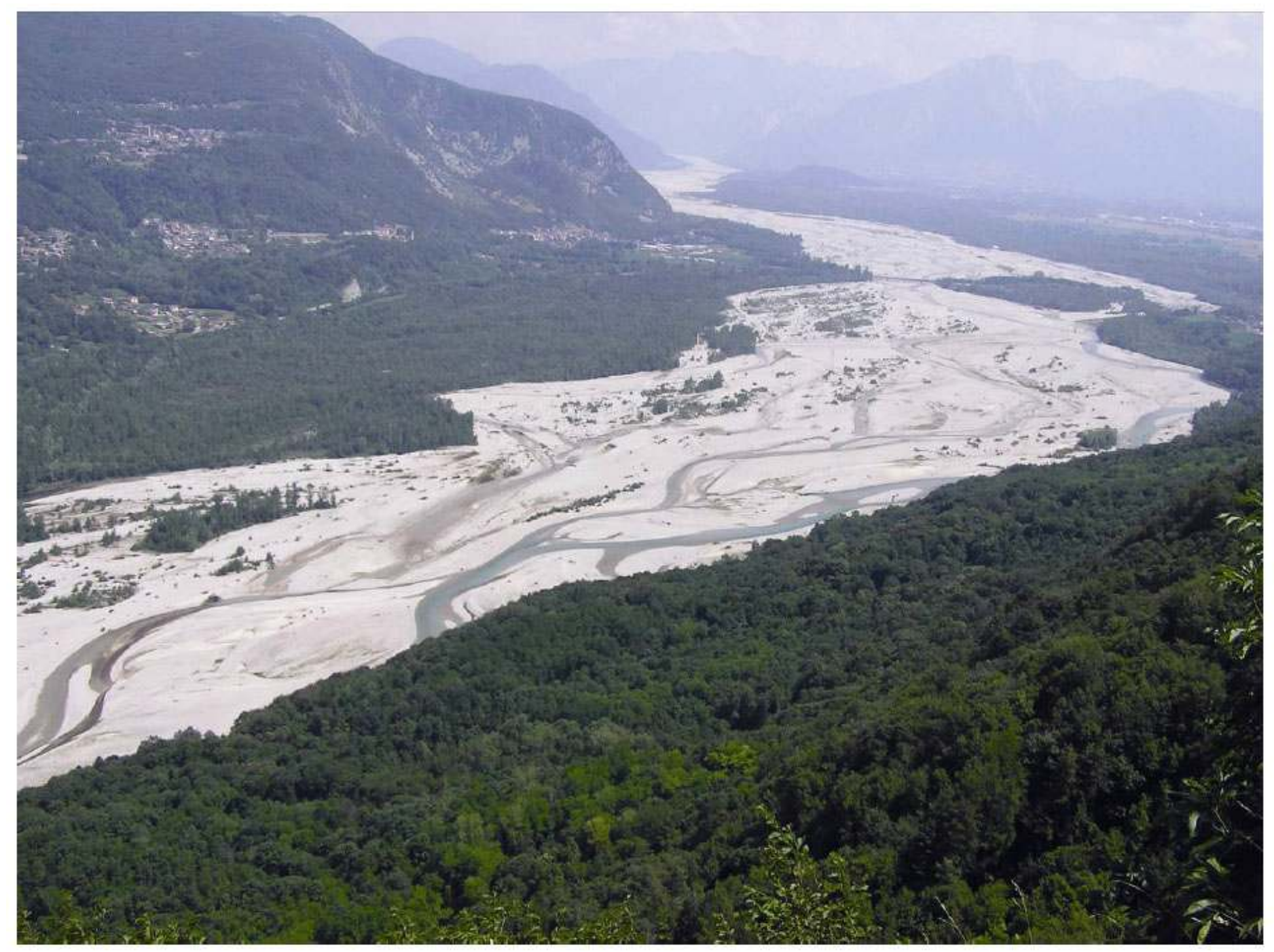

[Back to E090-240]

http://esapubs.org/Archive/ecol/E090/240/appendix-A.htm 


\section{Ecological Archives E090-240-A2}

Lukas Indermaur, Thomas Winzeler, Benedikt R. Schmidt, Klement Tockner, and Michael Schaub. 2009. Differential resource selection within shared habitat types across spatial scales in sympatric toads. Ecology 90:3430-3444.

Appendix B. Map of the study site.

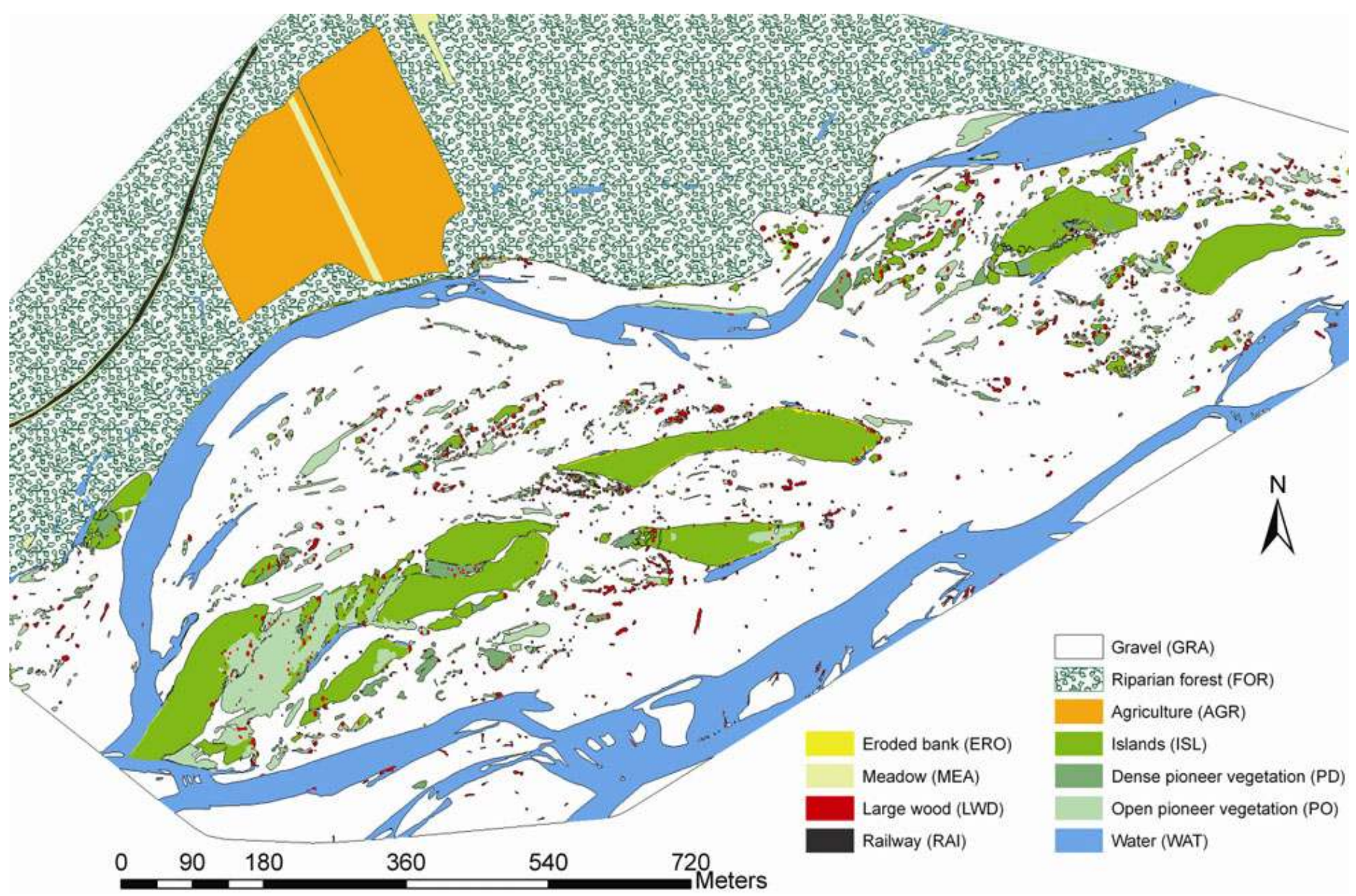

[Back to E090-240]

http://esapubs.org/Archive/ecol/E090/240/appendix-B.htm 


\section{Ecological Archives E090-240-A3}

Lukas Indermaur, Thomas Winzeler, Benedikt R. Schmidt, Klement Tockner, and Michael Schaub. 2009. Differential resource selection within shared habitat types across spatial scales in sympatric toads. Ecology 90:3430-3444.

Appendix C (TABLE C1). Candidate models used to evaluate the potential for differential resource selection within shared habitat types.

\begin{tabular}{|c|c|c|}
\hline \begin{tabular}{|l|} 
Model \\
No. $\dagger$
\end{tabular} & Covariates & Explanation \\
\hline 1 & $\mathrm{Pd}+T+\mathrm{Ht}+(\mathrm{Pd} \times T)+(\mathrm{Pd} \times \mathrm{Ht})+(T \times \mathrm{Ht})+(\mathrm{Pd} \times T \times \mathrm{Ht})$ & $\begin{array}{l}\text { Basic model } \\
\text { structure, } \\
\text { factor } \\
\text { species not } \\
\text { important }\end{array}$ \\
\hline 18 & $\mathrm{Pd}+T+\mathrm{Ht}+(\mathrm{Pd} \times T)+(\mathrm{Pd} \times \mathrm{Ht})+(T \times \mathrm{Ht})+(\mathrm{Pd} \times T \times \mathrm{Ht})+S+(\mathrm{Pd} \times S)+(T \times S)+(\mathrm{Ht} \times S)$ & \begin{tabular}{|l} 
Factor \\
species \\
important
\end{tabular} \\
\hline 19 & $\mathrm{Pd}+T+\mathrm{Ht}+(\mathrm{Pd} \times T)+(\mathrm{Pd} \times \mathrm{Ht})+(T \times \mathrm{Ht})+(\mathrm{Pd} \times T \times \mathrm{Ht})+S+(\mathrm{Pd} \times S)+(T \times S)+(\mathrm{Ht} \times S)$ & $\begin{array}{l}\text { Interaction } \\
\text { of prey } \\
\text { density with } \\
\text { species } \\
\text { important }\end{array}$ \\
\hline 20 & $\mathrm{Pd}+T+\mathrm{Ht}+(\mathrm{Pd} \times T)+(\mathrm{Pd} \times \mathrm{Ht})+(T \times \mathrm{Ht})+(\mathrm{Pd} \times T \times \mathrm{Ht})+S+(\mathrm{Pd} \times S)+(T \times S)+(\mathrm{Ht} \times S)$ & $\begin{array}{l}\text { Interaction } \\
\text { of } \\
\text { temperature } \\
\text { with species } \\
\text { important }\end{array}$ \\
\hline 21 & $\mathrm{Pd}+T+\mathrm{Ht}+(\mathrm{Pd} \times T)+(\mathrm{Pd} \times \mathrm{Ht})+(T \times \mathrm{Ht})+(\mathrm{Pd} \times T \times \mathrm{Ht})+S+(\mathrm{Pd} \times S)+(T \times S)+(\mathrm{Ht} \times S)$ & $\begin{array}{l}\text { Interaction } \\
\text { of prey } \\
\text { density and } \\
\text { temperature } \\
\text { with species } \\
\text { important }\end{array}$ \\
\hline 22 & $\mathrm{Pd}+T+\mathrm{Ht}+(\mathrm{Pd} \times T)+(\mathrm{Pd} \times \mathrm{Ht})+(T \times \mathrm{Ht})+(\mathrm{Pd} \times T \times \mathrm{Ht})+S+(\mathrm{Pd} \times S)+(T \times S)+(\mathrm{Ht} \times S)$ & $\begin{array}{l}\text { Interaction } \\
\text { of habitat } \\
\text { with species } \\
\text { important } \\
\end{array}$ \\
\hline 23 & $\mathrm{Pd}+T+\mathrm{Ht}+(\mathrm{Pd} \times T)+(\mathrm{Pd} \times \mathrm{Ht})+(T \times \mathrm{Ht})+(\mathrm{Pd} \times T \times \mathrm{Ht})+S+(\mathrm{Pd} \times S)+(T \times S)+(\mathrm{Ht} \times S)$ & $\begin{array}{l}\text { Full model. } \\
\text { Interaction } \\
\text { of prey } \\
\text { density, } \\
\text { temperature, } \\
\text { and habitat } \\
\text { with species } \\
\text { important. }\end{array}$ \\
\hline
\end{tabular}

Note: The best selected model out of Table 3 was combined with the additive and interactive effects of species $(S, 2$ levels) with log-prey density (Pd), temperature ( $T$ ), and habitat type (Ht, 5 levels).

$\dagger$ Due to increasing model complexity, some parameters did not fully converge among three independent chains, but parameter estimates were consistent when models were fitted repeatedly.

[Back to E090-240]

http://esapubs.org/Archive/ecol/E090/240/appendix-C.htm 
Lukas Indermaur, Thomas Winzeler, Benedikt R. Schmidt, Klement Tockner, and Michael Schaub. 2009. Differential resource selection within shared habitat types across spatial scales in sympatric toads. Ecology 90:3430-3444.

Appendix D. Model selection results for predicting habitat selection separately per species and spatial scale, sorted after the Deviance Information Criterion scores $(\Delta \mathrm{DIC})$.

\begin{tabular}{|c|c|c|c|c|c|c|c|c|c|c|}
\hline & \multicolumn{5}{|c|}{ B. b. spinosus } & \multicolumn{5}{|c|}{ B. viridis } \\
\hline Scale & $\begin{array}{c}\text { Model } \\
\text { No. }\end{array}$ & DEV & $\mathrm{pD}$ & $\Delta \mathrm{DIC}$ & weights & $\begin{array}{c}\text { Model } \\
\text { No. }\end{array}$ & DEV & $\mathrm{pD}$ & $\Delta \mathrm{DIC}$ & weights \\
\hline \multicolumn{11}{|c|}{ Home-range placement within floodplain } \\
\hline & 1 & 236 & 58 & 0.0 & 0.975 & 1 & 1076 & 89 & 0.0 & 0.512 \\
\hline & 2 & 245 & 55 & 7.3 & 0.025 & 2 & 1079 & 86 & 0.1 & 0.487 \\
\hline & 4 & 277 & 55 & 38.8 & 3.7E-09 & 4 & 1097 & 82 & 15.0 & $2.8 \mathrm{E}-04$ \\
\hline & 3 & 334 & 66 & 106.9 & $6.1 \mathrm{E}-24$ & 6 & 1154 & 75 & 64.5 & $5.2 \mathrm{E}-15$ \\
\hline & 5 & 358 & 69 & 134.6 & $5.9 \mathrm{E}-30$ & 3 & 1160 & 87 & 82.7 & $5.6 \mathrm{E}-19$ \\
\hline & 6 & 395 & 58 & 160.4 & $1.4 \mathrm{E}-35$ & 5 & 1193 & 80 & 109.0 & $1.1 \mathrm{E}-24$ \\
\hline & 7 & 409 & 62 & 176.9 & $3.8 \mathrm{E}-39$ & 9 & 1195 & 84 & 114.7 & $6.4 \mathrm{E}-26$ \\
\hline & 9 & 430 & 64 & 200.5 & $2.8 \mathrm{E}-44$ & 7 & 1233 & 70 & 139.1 & $3.3 \mathrm{E}-31$ \\
\hline & 10 & 546 & 63 & 316.3 & $2.0 \mathrm{E}-69$ & 10 & 1247 & 76 & 159.4 & $1.3 \mathrm{E}-35$ \\
\hline & 11 & 570 & 56 & 332.6 & $5.7 \mathrm{E}-73$ & 11 & 1277 & 66 & 178.4 & $9.6 \mathrm{E}-40$ \\
\hline & 8 & 875 & 61 & 643.1 & 2.2E-140 & 14 & 1869 & 54 & 758.9 & $8.4 \mathrm{E}-166$ \\
\hline & 12 & 1188 & 65 & 960.0 & 3.4E-209 & 15 & 1899 & 44 & 779.2 & $3.2 \mathrm{E}-170$ \\
\hline & 14 & 1229 & 44 & 979.7 & $1.7 \mathrm{E}-213$ & 8 & 2212 & 71 & 1118.5 & $6.8 \mathrm{E}-244$ \\
\hline & 13 & 1269 & 50 & 1026.0 & $1.6 \mathrm{E}-223$ & 12 & 2416 & 76 & 1327.5 & $2.8 \mathrm{E}-289$ \\
\hline & 15 & 1357 & 33 & 1096.5 & 7.6E-239 & 16 & 2481 & 23 & 1339.6 & $6.7 \mathrm{E}-292$ \\
\hline & 17 & 1948 & 20 & 1675.3 & $0.0 \mathrm{E}+00$ & 13 & 2596 & 47 & 1479.2 & $0.0 \mathrm{E}+00$ \\
\hline & 16 & 2622 & 20 & 2349.2 & $0.0 \mathrm{E}+00$ & 17 & 2907 & 26 & 1768.9 & $0.0 \mathrm{E}+00$ \\
\hline \multicolumn{11}{|c|}{ Space use within $95 \%$ home-range } \\
\hline & 1 & 1876 & 148 & 0.0 & 0.980 & 1 & 1199 & 146 & 0.0 & 0.782 \\
\hline & 2 & 1889 & 142 & 7.8 & 0.020 & 2 & 1207 & 141 & 2.5 & 0.218 \\
\hline & 4 & 1931 & 135 & 41.7 & $8.5 \mathrm{E}-10$ & 4 & 1245 & 135 & 35.1 & $1.9 \mathrm{E}-08$ \\
\hline & 3 & 1942 & 126 & 43.4 & $3.7 \mathrm{E}-10$ & 6 & 1283 & 129 & 67.2 & $2.0 \mathrm{E}-15$ \\
\hline & 5 & 1952 & 121 & 48.7 & $2.6 \mathrm{E}-11$ & 3 & 1279 & 135 & 68.7 & $9.4 \mathrm{E}-16$ \\
\hline & 6 & 1966 & 130 & 72.1 & $2.2 \mathrm{E}-16$ & 9 & 1327 & 127 & 109.6 & $1.2 \mathrm{E}-24$ \\
\hline & 9 & 1989 & 118 & 82.0 & $1.5 \mathrm{E}-18$ & 5 & 1327 & 131 & 112.7 & $2.6 \mathrm{E}-25$ \\
\hline & 7 & 2022 & 106 & 103.6 & $3.2 \mathrm{E}-23$ & 10 & 1374 & 120 & 149.2 & $3.1 \mathrm{E}-33$ \\
\hline & 10 & 2030 & 110 & 115.2 & $9.6 \mathrm{E}-26$ & 7 & 1462 & 114 & 231.6 & $4.1 \mathrm{E}-51$ \\
\hline & 11 & 2112 & 94 & 182.2 & $2.7 \mathrm{E}-40$ & 11 & 1514 & 103 & 272.2 & $6.0 \mathrm{E}-60$ \\
\hline & 8 & 2152 & 120 & 247.9 & $1.5 \mathrm{E}-54$ & 8 & 1985 & 124 & 763.4 & $1.3 \mathrm{E}-166$ \\
\hline & 12 & 2231 & 98 & 305.4 & $4.8 \mathrm{E}-67$ & 12 & 2106 & 110 & 871.1 & $5.6 \mathrm{E}-190$ \\
\hline & 13 & 2335 & 83 & 393.5 & $3.5 \mathrm{E}-86$ & 13 & 2358 & 92 & 1104.8 & $9.6 \mathrm{E}-241$ \\
\hline & 14 & 2501 & 59 & 536.4 & $3.3 \mathrm{E}-117$ & 14 & 2514 & 74 & 1243.4 & 7.8E-271 \\
\hline
\end{tabular}


Ecological Archives E090-240-A4

Seite 2 von 2

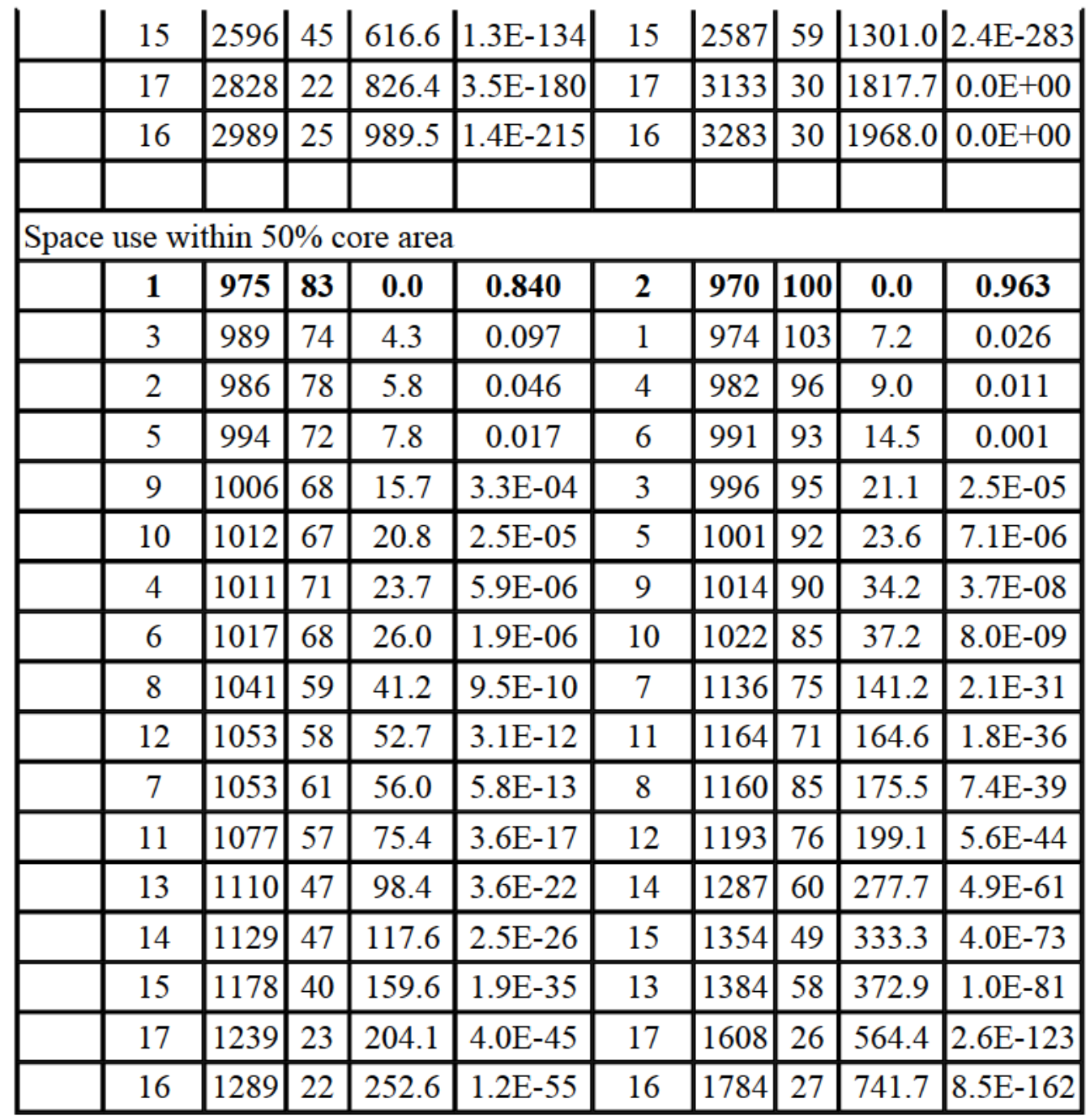

Notes: The best model is in bold type. See Table 2 for description of models. All factors were standardized prior to analysis. $\mathrm{DEV}=$ Deviance, $\mathrm{pD}=$ effective number of parameters, weights $=\mathrm{DIC}$ model weights. The $\triangle D I C$ is the difference of DIC between any model in the set to the best model. The smaller the $\triangle D I C$ the more similar is the fit compared with the best model (chosen as the model with $\triangle \mathrm{DIC}=0$ ). The top ranked model with $\triangle \mathrm{DIC}=0$ best approximates the data (Spiegelhalter et al. 2002). If model weights were equally distributed across models uncertainty in model selection would be maximal.

\section{LITERATURE CITED}

Spiegelhalter, D. J., N. G. Best, B. R. Carlin, and A. van der Linde. 2002. Bayesian measures of model complexity and fit. Journal of the Royal Statistical Society Series B, Statistical Methodology 64:583-616. 


\section{Lukas Indermaur, Thomas Winzeler, Benedikt R. Schmidt, Klement Tockner, and Michael Schaub. 2009. Differential resource selection within shared habitat types across spatial scales in sympatric toads. Ecology 90:3430-3444.}

Appendix E. Model selection results for exploring the potential for differential resource selection within shared habitat types, sorted after the Deviance Information Criterion scores $(\Delta \mathrm{DIC})$.

\begin{tabular}{|l|l|l|l|l|l|}
\hline Scale & $\begin{array}{c}\text { Model } \\
\text { No. }\end{array}$ & DEV & pD & $\Delta$ DIC & weights \\
\hline Home-range placement within floodplain \\
\hline & 22 & 1228.0 & 127.3 & 0.0 & 0.756 \\
\hline & 23 & 1231.0 & 126.9 & 2.5 & 0.213 \\
\hline & 20 & 1237.1 & 125.4 & 7.2 & 0.020 \\
\hline & 21 & 1239.7 & 125.1 & 9.4 & 0.007 \\
\hline & 18 & 1240.1 & 126.8 & 11.6 & 0.002 \\
\hline & 19 & 1240.3 & 128.4 & 13.3 & 0.001 \\
\hline & 1 & 1250.0 & 127.2 & 21.9 & 0.000 \\
\hline Space use within 95\% home-range \\
\hline & 23 & 2938.6 & 272.1 & 0.0 & 0.676 \\
\hline & 22 & 2939.7 & 272.4 & 1.5 & 0.323 \\
\hline & 18 & 2952.1 & 271.5 & 13.0 & 0.001 \\
\hline & 20 & 2958.2 & 270.7 & 18.3 & 0.000 \\
\hline & 21 & 2959.6 & 273.0 & 21.9 & 0.000 \\
\hline & 19 & 2966.2 & 274.4 & 29.9 & 0.000 \\
\hline & 1 & 2968.4 & 273.9 & 31.6 & 0.000 \\
\hline Space use within 50\% core area \\
\hline & 23 & 1877.7 & 181.0 & 0 & 0.941 \\
\hline & 21 & 1883.7 & 181.1 & 6.1 & 0.045 \\
\hline & 22 & 1888.5 & 179.8 & 9.6 & 0.008 \\
\hline & 20 & 1887.2 & 181.8 & 10.3 & 0.006 \\
\hline & 19 & 1890.6 & 183.4 & 15.3 & 0.000 \\
\hline & 18 & 1900.1 & 179.6 & 21.0 & 0.000 \\
\hline & 1 & 1899.5 & 187.5 & 28.3 & 0.000 \\
\hline
\end{tabular}

Notes: See Appendix C for description of models. These models were fitted to the pooled data of Bufo b. spinosus and $B$. viridis, separately for the three spatial scales. All factors were standardized prior to analysis.

$\mathrm{DEV}=$ Deviance, $\mathrm{pD}=$ effective number of parameters, weights $=\mathrm{DIC}$ model weights. The $\triangle \mathrm{DIC}$ is the difference of DIC between any model in the set to the best model. The smaller the $\Delta \mathrm{DIC}$ the more similar is the fit compared with the best model (chosen as the model with $\triangle \mathrm{DIC}=0$ ). The top ranked model with $\triangle \mathrm{DIC}=0$ best approximates the data (Spiegelhalter et al. 2002). If model weights were equally distributed across models uncertainty in model selection would be maximal.

\section{LITERATURE CITED}

Spiegelhalter, D. J., N. G. Best, B. R. Carlin, and A. van der Linde. 2002. Bayesian measures of model complexity and fit. Journal of the Royal Statistical Society Series B, Statistical Methodology 64:583-616. 
Lukas Indermaur, Thomas Winzeler, Benedikt R. Schmidt, Klement Tockner, and Michael Schaub. 2009. Differential resource selection within shared habitat types across spatial scales in sympatric toads. Ecology 90:3430-3444.

Appendix F. Effect sizes (Beta) and measures of precision (SD, LCI, UCI, CV) for the 23 parameters out of the best selected model (Table 3), separately by species and spatial scale.

\begin{tabular}{|c|c|c|c|c|c|c|c|c|c|c|c|}
\hline & & \multicolumn{5}{|c|}{ Bufo bufo spinosus } & \multicolumn{5}{|c|}{ B. viridis } \\
\hline No. & Factor & Beta & $\mathrm{SD}$ & LCI & UCI & $\mathrm{CV}$ & Beta & $\mathrm{SD}$ & LCI & UCI & $\mathrm{CV}$ \\
\hline \multicolumn{12}{|c|}{ Home-range placement within floodplain } \\
\hline 1 & $\mathrm{Pd}$ & 2.645 & 1.142 & 0.408 & 4.882 & 0.432 & 1.018 & 1.113 & -1.164 & 3.200 & 1.094 \\
\hline 2 & $T$ & -3.570 & 1.199 & -5.920 & -1.221 & 0.336 & -3.969 & 1.077 & -6.080 & $-\mathbf{1 . 8 5 7}$ & 0.271 \\
\hline 3 & GRA & -1.815 & 0.342 & -2.485 & -1.145 & 0.188 & -1.701 & 0.198 & -2.090 & -1.312 & 0.117 \\
\hline 4 & LWD & 4.775 & 2.100 & 0.659 & 8.891 & 0.440 & 6.324 & 2.795 & 0.846 & 11.802 & 0.442 \\
\hline 5 & $\mathrm{PD}$ & 10.358 & 1.248 & 7.911 & 12.805 & 0.121 & 9.908 & 1.241 & 7.476 & 12.341 & 0.125 \\
\hline 6 & ISL & 10.640 & 1.217 & 8.255 & 13.026 & 0.114 & 7.628 & 2.029 & 3.651 & 11.605 & 0.266 \\
\hline 7 & ISLE & 11.301 & 0.851 & 9.633 & 12.969 & 0.075 & 10.297 & 1.085 & 8.170 & 12.425 & 0.105 \\
\hline 8 & $\mathrm{Pd} \times T$ & 1.720 & 1.680 & -1.573 & 5.012 & 0.977 & -3.577 & 2.092 & -7.678 & 0.523 & 0.585 \\
\hline 9 & $T \times \mathrm{GRA}$ & -1.547 & 1.336 & -4.165 & 1.071 & 0.863 & 1.624 & 1.356 & -1.033 & 4.282 & 0.835 \\
\hline 10 & $T \times \mathrm{LWD}$ & -7.245 & 2.059 & -11.280 & -3.210 & 0.284 & -8.707 & 1.752 & -12.142 & -5.273 & 0.201 \\
\hline 11 & $T \times \mathrm{PD}$ & 1.496 & 2.226 & -2.867 & 5.860 & 1.488 & 0.574 & 2.098 & -3.537 & 4.685 & 3.655 \\
\hline 12 & $T \times \mathrm{ISL}$ & -6.991 & 2.378 & -11.652 & -2.330 & 0.340 & -4.021 & 2.979 & -9.859 & 1.818 & 0.741 \\
\hline 13 & $T \times \mathrm{ISLE}$ & 11.008 & 1.135 & 8.783 & 13.233 & 0.103 & 10.577 & 1.204 & 8.218 & 12.937 & 0.114 \\
\hline 14 & $\mathrm{Pd} \times \mathrm{GRA}$ & 1.852 & 1.170 & -0.441 & 4.144 & 0.632 & 2.575 & 1.100 & 0.420 & 4.731 & 0.427 \\
\hline 15 & $\mathrm{Pd} \times \mathrm{LWD}$ & 0.274 & 3.244 & -6.083 & 6.632 & 11.823 & -1.570 & 3.059 & -7.565 & 4.426 & 1.949 \\
\hline 16 & $\mathrm{Pd} \times \mathrm{PD}$ & 5.696 & 1.710 & 2.345 & 9.048 & 0.300 & -1.405 & 2.034 & -5.391 & 2.582 & 1.448 \\
\hline 17 & $\mathrm{Pd} \times \mathrm{ISL}$ & -2.201 & 1.901 & -5.926 & 1.524 & 0.863 & -0.670 & 2.569 & -5.704 & 4.365 & 3.836 \\
\hline 18 & $\mathrm{Pd} \times$ ISLE & -0.586 & 1.591 & -3.705 & 2.533 & 2.715 & 3.155 & 2.405 & -1.558 & 7.868 & 0.762 \\
\hline 19 & $\mathrm{Pd} \times T \times \mathrm{GRA}$ & 4.523 & 1.635 & 1.317 & 7.728 & 0.362 & 2.014 & 2.367 & -2.624 & 6.653 & 1.175 \\
\hline 20 & $\mathrm{Pd} \times T \times \mathrm{LWD}$ & -2.925 & 2.530 & -7.884 & 2.033 & 0.865 & 3.853 & 2.542 & -1.129 & 8.835 & 0.660 \\
\hline 21 & $\mathrm{Pd} \times T \times \mathrm{PD}$ & -5.246 & 2.293 & -9.740 & -0.753 & 0.437 & -2.025 & 2.603 & -7.126 & 3.076 & 1.285 \\
\hline 22 & $\mathrm{Pd} \times T \times \mathrm{ISL}$ & 0.423 & 2.649 & -4.769 & 5.615 & 6.265 & 1.855 & 2.831 & -3.695 & 7.405 & 1.526 \\
\hline 23 & $\mathrm{Pd} \times T \times \mathrm{ISLE}$ & 1.345 & 1.735 & -2.055 & 4.745 & 1.290 & -3.498 & 2.068 & -7.552 & 0.555 & 0.591 \\
\hline \multicolumn{12}{|c|}{ Space use within $95 \%$ home-range } \\
\hline 1 & $\mathrm{Pd}$ & 1.534 & 1.499 & -1.404 & 4.472 & 0.977 & -0.284 & 1.034 & -2.311 & 1.742 & 3.635 \\
\hline 2 & $T$ & 0.265 & 1.660 & -2.988 & 3.519 & 6.257 & -0.692 & 1.383 & -3.403 & 2.019 & 1.998 \\
\hline 3 & GRA & -0.068 & 0.626 & -1.295 & 1.160 & 9.270 & 0.939 & 0.583 & -0.203 & 2.082 & 0.620 \\
\hline 4 & LWD & 4.313 & 2.034 & 0.327 & 8.299 & 0.471 & 4.263 & 2.481 & -0.599 & 9.125 & 0.582 \\
\hline 5 & $\mathrm{PD}$ & 1.821 & 0.622 & 0.601 & 3.041 & 0.342 & 5.435 & 0.663 & 4.135 & 6.735 & 0.122 \\
\hline 6 & ISL & 1.772 & 0.462 & 0.867 & 2.678 & 0.261 & 2.587 & 1.019 & 0.591 & 4.584 & 0.394 \\
\hline 7 & ISLE & 2.086 & 0.613 & 0.884 & 3.289 & 0.294 & -0.105 & 0.844 & -1.758 & 1.549 & 8.069 \\
\hline 8 & $\mathrm{Pd} \times T$ & 2.847 & 1.456 & -0.007 & 5.701 & 0.511 & -0.478 & 1.372 & -3.166 & 2.211 & 2.872 \\
\hline
\end{tabular}




\begin{tabular}{|c|c|c|c|c|c|c|c|c|c|c|c|}
9 & $T \times$ GRA & -0.305 & 1.631 & -3.502 & 2.892 & 5.345 & $\mathbf{4 . 2 9 6}$ & $\mathbf{1 . 4 8 0}$ & $\mathbf{1 . 3 9 6}$ & $\mathbf{7 . 1 9 7}$ & $\mathbf{0 . 3 4 4}$ \\
\hline 10 & $T \times$ LWD & 1.980 & 2.007 & -1.954 & 5.913 & 1.014 & $\mathbf{- 4 . 1 9 3}$ & $\mathbf{1 . 9 9 3}$ & $\mathbf{- 8 . 1 0 0}$ & $\mathbf{- 0 . 2 8 7}$ & $\mathbf{0 . 4 7 5}$ \\
\hline 11 & $T \times$ PD & 0.835 & 1.657 & -2.412 & 4.082 & 1.984 & -2.284 & 1.560 & -5.341 & 0.774 & 0.683 \\
\hline 12 & $T \times$ ISL & -0.159 & 1.735 & -3.560 & 3.241 & 10.882 & $\mathbf{- 5 . 5 6 9}$ & $\mathbf{2 . 2 0 5}$ & $\mathbf{- 9 . 8 9 1}$ & $\mathbf{- 1 . 2 4 7}$ & $\mathbf{0 . 3 9 6}$ \\
\hline 13 & $T \times$ ISLE & -1.603 & 1.676 & -4.888 & 1.682 & 1.046 & -2.875 & 1.548 & -5.910 & 0.160 & 0.539 \\
\hline 14 & Pd $\times$ GRA & -0.918 & 1.669 & -4.189 & 2.354 & 1.819 & -1.224 & 1.006 & -3.196 & 0.747 & 0.822 \\
\hline 15 & Pd $\times$ LWD & 1.122 & 2.549 & -3.873 & 6.118 & 2.271 & -0.344 & 1.885 & -4.040 & 3.351 & 5.478 \\
\hline 16 & Pd $\times$ PD & 0.080 & 1.664 & -3.181 & 3.340 & 20.915 & 0.579 & 1.082 & -1.542 & 2.701 & 1.868 \\
\hline 17 & Pd $\times$ ISL & -1.410 & 1.746 & -4.832 & 2.013 & 1.239 & -1.206 & 1.449 & -4.045 & 1.633 & 1.201 \\
\hline 18 & Pd $\times$ ISLE & -1.518 & 1.676 & -4.802 & 1.766 & 1.104 & $\mathbf{3 . 7 5 6}$ & $\mathbf{1 . 2 7 5}$ & $\mathbf{1 . 2 5 7}$ & $\mathbf{6 . 2 5 6}$ & $\mathbf{0 . 3 3 9}$ \\
\hline 19 & $\mathrm{Pd} \times T \times$ GRA & -0.648 & 1.743 & -4.064 & 2.768 & 2.690 & $\mathbf{3 . 8 9 9}$ & $\mathbf{1 . 3 9 4}$ & $\mathbf{1 . 1 6 6}$ & $\mathbf{6 . 6 3 2}$ & $\mathbf{0 . 3 5 8}$ \\
\hline 20 & $\mathrm{Pd} \times T \times$ LWD & -1.347 & 1.696 & -4.670 & 1.977 & 1.259 & 0.573 & 1.655 & -2.672 & 3.817 & 2.891 \\
\hline 21 & $\mathrm{Pd} \times T \times$ PD & $-\mathbf{4 . 3 6 2}$ & $\mathbf{1 . 6 2 1}$ & $\mathbf{- 7 . 5 3 9}$ & $\mathbf{- 1 . 1 8 6}$ & $\mathbf{0 . 3 7 2}$ & -2.214 & 1.751 & -5.647 & 1.219 & 0.791 \\
\hline 22 & $\mathrm{Pd} \times T \times$ ISL & -1.755 & 1.671 & -5.031 & 1.521 & 0.952 & -4.207 & 2.256 & -8.629 & 0.215 & 0.536 \\
\hline 23 & $\mathrm{Pd} \times T \times$ ISLE & -1.487 & 1.693 & -4.806 & 1.832 & 1.139 & 1.261 & 1.687 & -2.044 & 4.567 & 1.337 \\
\hline & & & & & & & & & &
\end{tabular}

Space use within $50 \%$ core area

\begin{tabular}{|c|c|c|c|c|c|c|c|c|c|c|c|}
\hline 1 & $\mathrm{Pd}$ & 886 & 2.469 & -9.724 & 0.047 & 0.505 & 3.499 & 1.648 & 0.269 & 6.730 & 0.471 \\
\hline & 1 & 21 & 90 & 22 & 0.580 & 9 & 991 & 36 & 39 & 7 & 0 \\
\hline & & 7 & 1 & 5 & 5.710 & 8 & 0 & 5 & 4 & 4 & 023 \\
\hline & & 611 & 0 & 975 & & 5 & 6 & 513 & -10 & 11 & 454 \\
\hline & 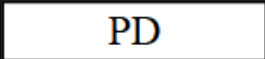 & 28 & 0.372 & 0.757 & 0.700 & 126 & 2.680 & 0.690 & 1.328 & 4.033 & 257 \\
\hline & & 1.205 & 2 & 0.652 & 1 & 4 & 7 & 009 & 1 & 4 & 2.031 \\
\hline & $\mathrm{LE}$ & 137 & 0.438 & -1.995 & -0.279 & 85 & 1.364 & 0.991 & -0.578 & .307 & 727 \\
\hline . & $T$ & 4.293 & 1.878 & 0.613 & 7.974 & 0.437 & 3.484 & 1.487 & 0.569 & 6.398 & 427 \\
\hline 9 & $T \times \mathrm{GRA}$ & 0 & 8 & -4.139 & 8 & 5.696 & 3.277 & 1.856 & -0.361 & 6.916 & 80 \\
\hline & 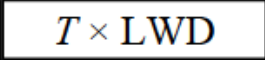 & 02 & 720 & 730 & 8.934 & 55 & 39 & 2.067 & 1 & 37 & 87 \\
\hline 1 & $\times \mathrm{PD}$ & 6.426 & 1.946 & 2.612 & 10.240 & 0.303 & -1.293 & 1.925 & -5.065 & 2.479 & 1.488 \\
\hline & 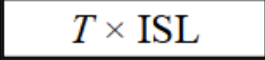 & 5 & 39 & 6 & 6 & 5 & 6 & 3 & -1 & 38 & 382 \\
\hline 1 & -1 & 2.445 & 1.891 & -1.261 & | & 0.773 & 4 & 7 & 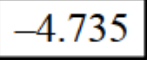 & $t$ & 1.513 \\
\hline 12 & $\times$ GRA & -3.855 & 2.933 & -9.604 & 1.893 & 0.761 & -1.613 & 1.907 & -5.351 & 2.125 & 182 \\
\hline 1 & $<\mathrm{LWD}$ & 6.374 & 2.097 & 2.265 & 10.483 & 0.329 & -4.591 & 2.908 & -10.290 & 1.107 & 0.633 \\
\hline & PD & 00 & L.2.0J & 1.708 & .000 & 0.724 & -4.171 & 1.917 & -7.928 & 0.717 & 70 \\
\hline 17 & ISL & 4 & 2.97 & 3 & 10.810 & 0 & 74 & 2.385 & -1 & 49 & 87 \\
\hline 18 & $\mathrm{Pd} \times$ ISLE & 3.699 & 3.080 & -2.338 & 9.737 & 0.833 & 0.266 & 2.264 & -4.170 & 4.703 & 8.497 \\
\hline 19 & $1 \times T \times$ GRA & 3.159 & 2.088 & -0.934 & 7.251 & 0.661 & -3.865 & 1.519 & -6.842 & -0.888 & 0.393 \\
\hline 20 & $\mathrm{~d} \times T \times \mathrm{LWD}$ & -4.047 & 1.824 & -7.622 & -0.472 & 0. & -4.427 & 2.268 & -8.873 & 18 & 0 \\
\hline 21 & $\mathrm{Pd} \times T \times \mathrm{PD}$ & -0.560 & 1.978 & -4.438 & 3.317 & 3.529 & -1.111 & 1.804 & -4.646 & 2.425 & 1.624 \\
\hline 22 & $\mathrm{Pd} \times T \times \mathrm{ISL}$ & -5.102 & 1.823 & -8.674 & 30 & 7 & 6 & 2.526 & -2 & 06 & 1.25 \\
\hline 23 & $\mathrm{~d} \times T \times \mathrm{ISLE}$ & -1.874 & 1.956 & 5.708 & 1.961 & 1.044 & 0.104 & 2.447 & -4.692 & .900 & 23.5 \\
\hline
\end{tabular}

Notes: Pd = Prey density, $T=$ Temperature, see Table 1 for abbreviations of habitat types GRA, LWD, PD, ISL, and ISLE. Beta $=$ Regression slope for population, $\mathrm{SD}=$ Standard deviation, $\mathrm{LCI}=$ Lower $95 \%$ confidence interval, $\mathrm{UCI}=$ Upper $95 \%$ confidence interval, $\mathrm{CV}=$ Coefficient of variation (SD/Beta). Effect sizes that did not include zero in $95 \%$ confidence intervals are in bold type. 
Seite 3 von 3 
Lukas Indermaur, Thomas Winzeler, Benedikt R. Schmidt, Klement Tockner, and Michael Schaub. 2009. Differential resource selection within shared habitat types across spatial scales in sympatric toads. Ecology 90:3430-3444.

Appendix G. Predicted selection probabilities in relation to the habitat type exposed gravel sediments, log-prey density, and temperature, separately by species and scale.

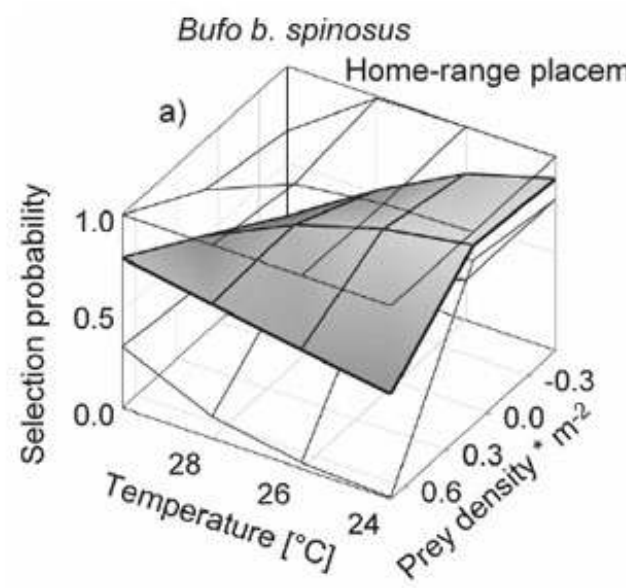

B. viridis
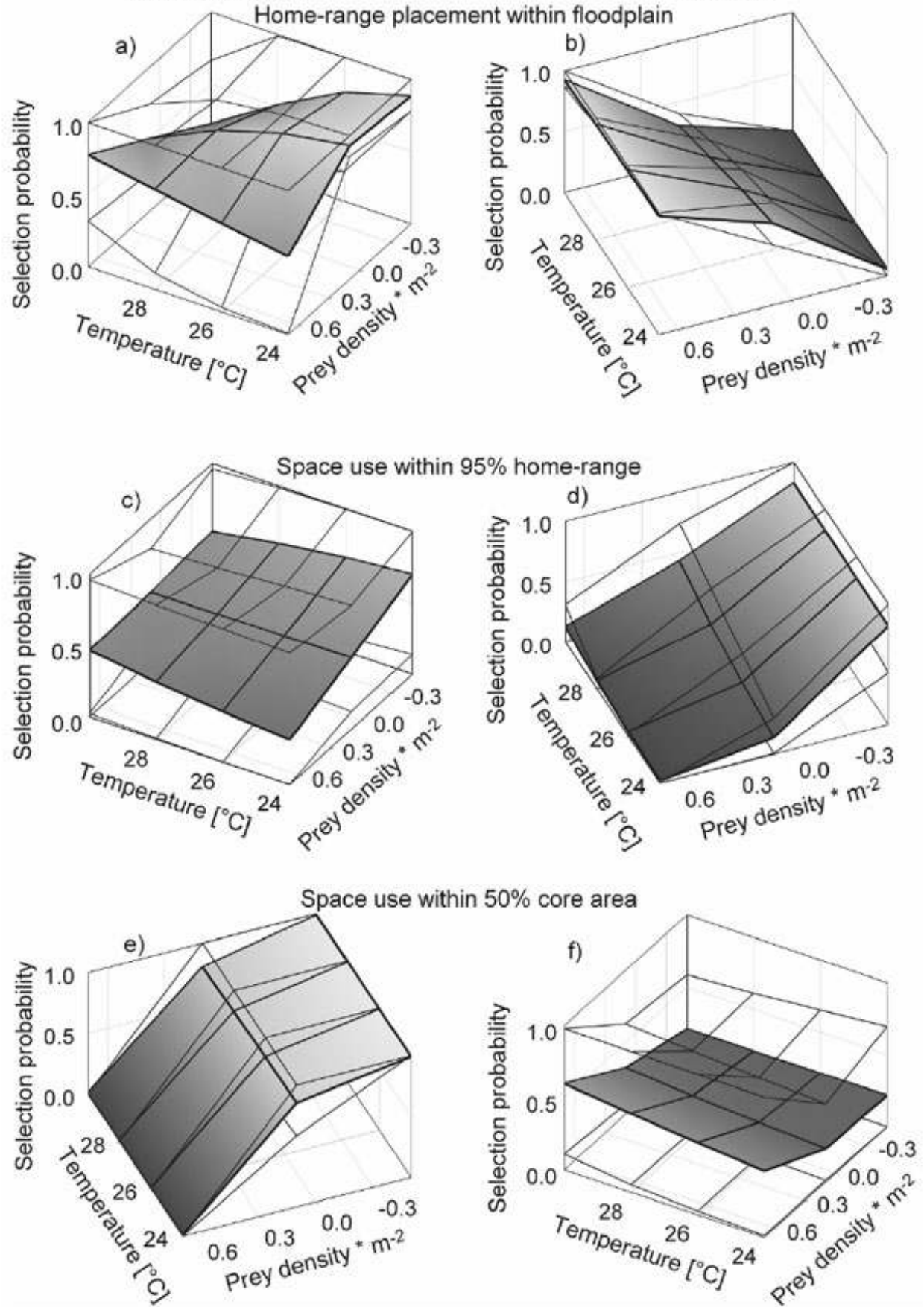

FIG. G1. Predicted selection probabilities in relation to the habitat type exposed gravel sediments, log-prey density, and temperature, separately by species and scale. The model that best explained habitat selection was used to predict selection probabilities (Table 3, Appendix D). Predictions were done for constant low (-0.5), intermediate (0.1), and high log-prey density (0.7), as well as for 14 temperature values ranging from $20^{\circ} \mathrm{C}$ to $46^{\circ} \mathrm{C}$. Shaded areas are mean selection probabilities, whereas transparent areas indicate the lower and upper $95 \%$ confidence interval. If there is no selection, the selection probability $(P)$ is 0.5 , if there is avoidance $P<0.5$, and if there is preference $P>0.5$. When the selection surface parallels the $x$ - and $y$ axes, selection is independent of prey and temperature. 
Lukas Indermaur, Thomas Winzeler, Benedikt R. Schmidt, Klement Tockner, and Michael Schaub. 2009. Differential resource selection within shared habitat types across spatial scales in sympatric toads. Ecology 90:3430-3444.

Appendix H. Predicted selection probabilities in relation to the habitat type established islands, log-prey density, and temperature, separately by species and scale.
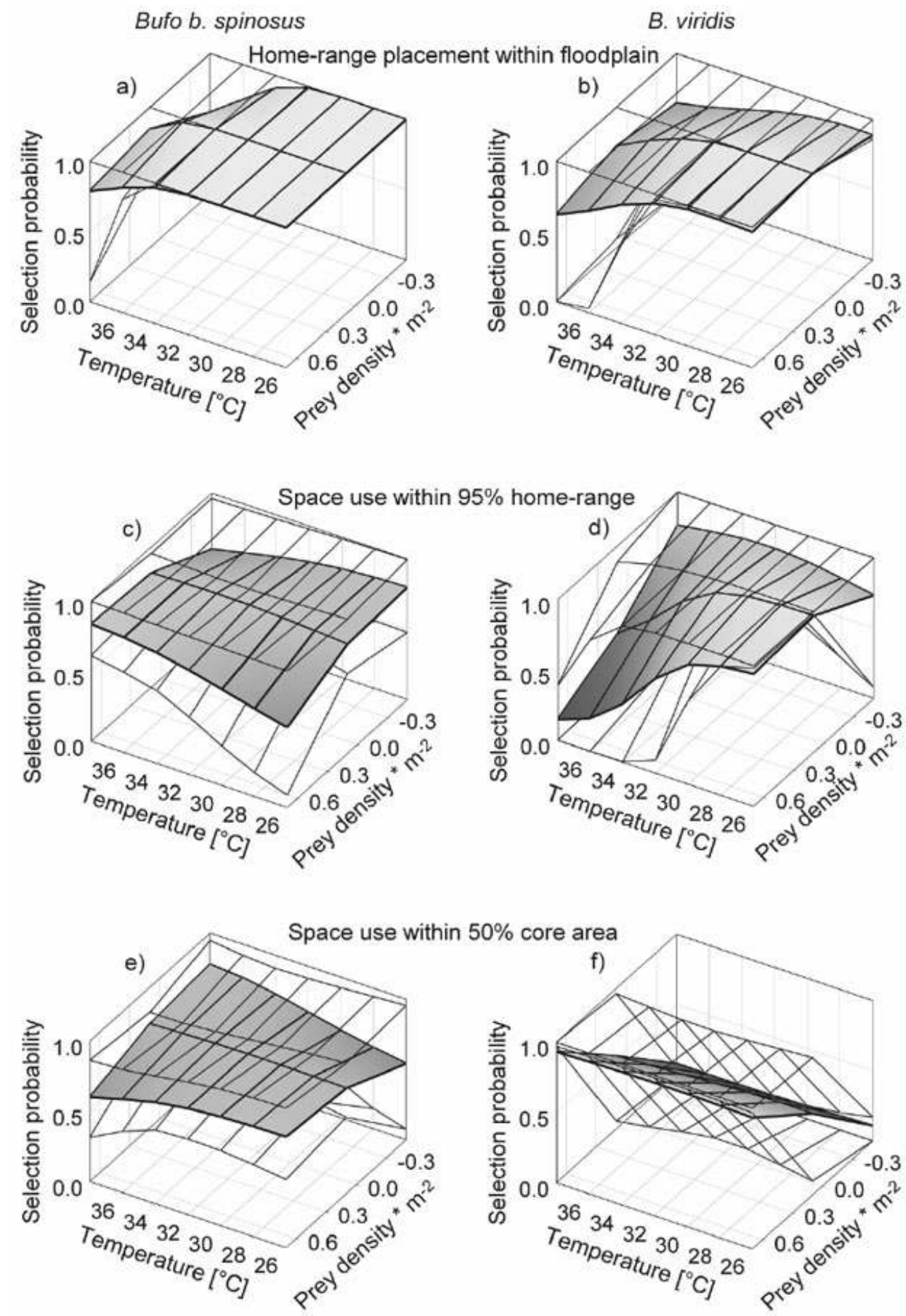

FIG. H1. Predicted selection probabilities in relation to the habitat type established islands, log-prey density, and temperature, separately by species and scale. The model that best explained habitat selection was used to predict selection probabilities (Table 3 , Appendix D). Predictions were done for constant low (-0.5), intermediate (0.1), and high log-prey density (0.7) as well as for 14 temperature values ranging from $20^{\circ} \mathrm{C}$ to $46^{\circ} \mathrm{C}$. Shaded areas are mean selection probabilities, whereas transparent areas indicate the lower and upper $95 \%$ confidence interval. If there is no selection, the selection probability $(P)$ is 0.5 , if there is avoidance $P<0.5$, and if there is preference $P>0.5$. When the selection surface parallels the $x$ - and $y$ axes, selection is independent of prey and temperature. 